REVISTA DE DERECHO UNED, NÚM. 22, 2018

\title{
EVOLUCIÓN HISTÓRICA DE LA APLICACIÓN DEL DERECHO EXTRANJERO EN EL PROCESO CIVIL ESPAÑOL
}

\author{
HISTORICAL EVOLUTION OF THE APPLICATION \\ OF FOREIGN LAW IN THE SPANISH CIVIL PROCESS
}

Juan Manuel Alonso Furelos

Prof. T.U. Derecho Procesal. UNED

\begin{abstract}
Sumario: Abordo en el trabajo la aplicación del derecho material privado en la sentencia - sea en primera instancia, en segunda o casación- en el proceso tramitado en España ante nuestros jueces y tribunales del orden civil de la jurisdicción ordinaria.

Desde que existen textos legales conocidos y hasta la segunda mitad del S. XIX se aplicó exclusivamente el derecho nacional tanto a los españoles como a los extranjeros, aunque se permitió excepcionalmente en dicha jurisdicción civil ordinaria y real la aplicación del derecho romano y canónico en cuanto formase parte de la «doctrina considerada auténtica» de determinados romanistas y canonistas.
\end{abstract}

A partir de la segunda mitad del S. XIX, por virtud de la LEC 1855 (juicio de reconocimiento de sentencias extranjeras) y la doctrina legal de nuestro Tribunal Supremo al pronunciarse en los recursos de casación por infracción de ley se permitirá la prueba y aplicación del derecho extranjero en el proceso civil seguido en España ante nuestros jueces y tribunales. (Aunque escasa fue su doctrina legal al pronunciarse sobre los recursos de casación por quebrantamiento de las formas esenciales del juicio referidas a la actividad probatoria del derecho extranjero causantes de indefensión). 
Este trabajo sigue el sistema histórico-cronológico destacando los periodos e hitos considerados más sobresalientes.

Palabras clave: Proceso civil español. Aplicación derecho privado nacional y extranjero.

Abstract: I approach in the work the application of private material right in the judgment - be it in the first instance, in second or cassation - in the process processed in Spain before our judges and courts of the civil order of the ordinary jurisdiction.

Since there are known legal texts and until the second half of the 19th century applied exclusively the national law both to the Spaniards and to the foreigners, although there was allowed exceptionally in the above mentioned civil ordinary and royal jurisdiction the application of the roman and canon law in all that it was forming a part of the «doctrine considered authentic» of certain romanists and canonists.

From the second half of the 19th century, by virtue of the LEC 1855 (judgment of recognition of foreign judgments) and the legal doctrine of our Supreme Court on having declared in the appeals in cassation for infraction of law will allow itself the test and application of the foreign right in the civil process followed in Spain before our judges and courts. (although there was little legal doctrine to pronounce on appeals in cassation for breach of the essential procedure of the trial referred to the evidential activity of foreign law causing defenselessness).

This work follows the historical-chronological system highlighting the periods and milestones considered most outstanding.

Keywords: Spanish civil process. National and foreign private law application.

Recepción original: 22/12/2017

Aceptación original: 24/01/2018

Sumario: I. Introducción. II. Derecho Romano. III. Derecho visigodo. IV. La caída del Estado visigótico. La Alta Edad Media. V. La Baja Edad Media y la doctrina Estatutaria Europea. VI. La baja Edad Media Española a la luz de sus textos jurídicos. VII. La Edad Moderna. VIII. Los inicios de la Edad Contemporánea en España. IX. La Restauración Fernandina. Vuelta al modelo constitucional. X. Precedentes a la reforma. El proyecto de García Goyena de Código Civil de 1851. El Decreto de Extranjería de 17-11-1852. El establecimiento en España en 1852 del recurso de casación por infracción de ley y doctrina legal com- 
petencia exclusiva del TS. La instrucción del procedimiento civil de 1853. XI. La Ley de Enjuiciamiento civil de 1855. XII. jurisprudencia de la Sala Civil del TS en recursos de casación por infracción de ley o su doctrina legal al amparo de las Leyes de Enjuiciamiento civil de 1855 y 1881. XIII. El Decreto de Unificación de Fueros y la Ley Provisional del Poder Judicial de 1870. La LEC de 1881. XIV. El Código Civil de $1888-89$ y el sistema de las normas de conflicto. XV. La reforma de 1974. XVI. Legislación del periodo constitucional. XVII. La LEC 2000. XVIII. La Ley 29/2015 de 30 de Julio de Cooperación Jurídica en materia civil. XIX. Conclusiones. XX. Bibliografía.

\section{INTRODUCCIÓN}

El Estado al aplicar las normas al caso concreto, a lo largo de la historia y como manifestación de su Soberanía, ha optado entre dos sistemas en principio extremos: negar o no reconocer la extranjería y de esta forma no regular o no reconocer derechos a los extranjeros (sean de naturaleza privada o pública) o limitarlos al máximo por dicha condición y al margen de la limitada o plena capacidad jurídica de los extranjeros. Así ocurría en las sociedades primitivas respecto a los pueblos vencidos, tras ser conquistados y esclavizados; o por el contrario reconocer derechos a los extranjeros (dígase a la condición jurídica de la extranjería) para igualar ciertos derechos de estos, con los de los nacionales; o al menos equipararlos a los de ellos en menor medida, como sucedió a medida que los Estados avanzaron, se desarrollaron y relacionaron económicamente entre sí, desde la segunda mitad del S. XIX.

Y en este último caso de equiparación caben a su vez, dos modelos: establecer que los derechos subjetivos materiales y privados de los extranjeros se actúen por los jueces y tribunales conforme a la ley nacional del país ante el que solicitan la tutela judicial y donde pueden ser actuados; es decir conforme a la ley del tribunal del foro y en la misma forma o muy semejante que a los nacionales de éste. O que puedan actuarse en el ámbito del derecho privado (en especial si pertenecen al derecho civil o mercantil), según la ley material privada del país extranjero (si es conforme a la ley de su estatuto personal en materias referidas a dicha cuestión; o según la ley del lugar en que se consumó el contrato y según las formas exigidas en éste — «lex regit actum»—).

En este último supuesto caben a su vez dos manifestaciones diferentes y que vienen (en cierta medida) a actuar (o a ser) como las dos caras de una misma moneda. 
a) La primera sería reconocer la efectividad del derecho extranjero (el derecho privado civil, mercantil o incluso otro derecho privado) en el proceso de declaración que se sigue ante el orden jurisdiccional (suele ser el orden jurisdiccional civil, con la excepción del laboral en tales casos) correspondiente del Estado del foro. Es decir, permitir que los órganos jurisdiccionales del Estado del foro - es decir, de aquel en que se tramita dicho proceso civil de declaración según la norma procesal del foro, art. 3 LEC - puedan aplicar el derecho extranjero en la sentencia que dicten, y después - en el momento procedente- permitir la ejecución material de la sentencia dictada según este derecho extranjero en el proceso de ejecución (ejecución procesal) que se siga y que casi siempre se tramitará según la norma procesal del foro, art. 3 LEC.

Pero para aplicarlo al caso concreto, al ser por lo común desconocido a sus órganos jurisdiccionales, es necesario que se proceda a su prueba, a instancia de parte — por los interesados en ella-; o por los propios órganos jurisdiccionales de oficio. $\mathrm{O}$ que se pueda aplicar directamente de oficio por los jueces y tribunales, merced a un adecuado y complejo sistema de información del derecho extranjero (lo que supone una manifestación de la colaboración jurisdiccional en el orden internacional) por parte de las autoridades (judiciales o administrativas) del país extranjero.

b) La segunda manifestación es permitir que la sentencia dictada en un país extranjero (y por esto extranjera) —en la que se aplicó ese derecho extranjero- si tuviera que producir efectos en otro país deba de ser reconocida, homologada y en su caso ejecutada por éste. A salvo que este trámite fuera innecesario en un sistema óptimo de colaboración entre Estados (Convenio o Tratado Internacional bi o multilateral), y con un modelo jurídico de gran homogeneidad; es decir que los efectos de la cosa juzgada de la sentencia extranjera fueran idénticos desde su producción a las de la sentencia nacional y no se precisara tal trámite de homologación, comprobación o reconocimiento por muy «suave o leve» que fuera ese trámite en lo material o formal.

Así, si la pretensión reconocida en esa sentencia extranjera es de mera declaración para producir efectos en España deberá ser reconocida u homologada. Igual sucede si la pretensión reconocida en esa sentencia extranjera fuese constitutiva (la que crea, modifica o extingue la relación o situación jurídica material originaria sea «ex nunc» o «ex tunc» a la propia sentencia y sí se retrotrae, si lo es al momento de la litispendencia o al momento del hecho causante de la misma). En estos casos, si fuera precisa su inscripción en el registro público 
correspondiente, el órgano jurisdiccional acordará en la sentencia, o por auto una vez firme que se proceda a su inscripción, sin que tal inscripción ordenada al funcionario suponga de por sí un proceso de ejecución.

Finalmente, si la pretensión reconocida en la sentencia extranjera fuera de condena será preciso su reconocimiento, comprobación u homologación y tras ello se procederá a su ejecución material (contenido material de esa sentencia) y procesal a instancia de parte dentro del plazo común establecido a través de las normas reguladoras del proceso común de ejecución procesal.

En ambos supuestos o manifestaciones se aplica (declara) y en su caso ejecuta (ejecución material) al caso concreto, el derecho extranjero. En el primero en el país del foro. En el segundo en el país de origen, pero debe homologarse, comprobarse o reconocerse para en su caso después ejecutarse (si la pretensión estimada en la sentencia es declarativa de condena) en el país del foro, donde debe producir efectos.

Cierto que la primera manifestación (alegar, fundamentar, probar y aplicar el derecho extranjero) no supone una modificación del trámite procesal del proceso de declaración (o ejecución) que es el mismo que cuando se trata de un proceso nacional sin elemento extranjero. Sólo, en su caso, habrá que probar ese derecho extranjero para que se aplique en la sentencia, cuando se exige.

Y en la segunda, existirá un proceso civil -especial y complejo por el trámite y el fin pretendido- de declaración para su homologación o reconocimiento. De naturaleza jurídica especial por razón de la materia que lo distingue de otros procesos de declaración; más o menos sencillo o complejo según los requisitos que se exijan para ello. Bajo una estructura o trámite especial que lo aleja y diferencia de los demás tipos procedimentales de declaración por su finalidad que es el reconocimiento, homologación, comprobación o adecuación de esa sentencia extranjera con nuestro ordenamiento jurídico (cuyo fin no se olvide es el respeto del orden público nacional, así como evitar el fraude de ley material o procesal).

Además, se podría considerar como una fase especial (competencia funcional por razones internacionales) añadida a la seguida en el país de origen si afirmamos que la sentencia extranjera no tiene en España el carácter de cosa juzgada pues este carácter es inmanente a la jurisdicción nacional (art. $117 \mathrm{CE}$ ) y por ello carece de ella antes de su reconocimiento, homologación. La homologación, el reconocimiento, la declaración de su adecuación con nuestro sistema por 
nuestros órganos judiciales le confiere ese carácter de cosa juzgada (aunque fuese antes firme) que antes no tenía. (Art. $117 \mathrm{CE}$ ).

Es decir, en ambos casos, la aplicación del derecho extranjero en España previa su prueba, o el control del que fue aplicado debidamente en otro país en forma semejante al nuestro hasta "cierta medida» responden a semejante objeto o fin y por ello hablaba de las dos caras de una misma moneda: el respeto al orden público nacional del país del foro manifestado en ese derecho que se aplica o reconoce; así como evitar el fraude a la ley nacional, material o procesal; y el respeto a los derechos fundamentales de nuestro sistema jurídico que coinciden en la cultura occidental y angloamericana con el respeto a unos mismos o semejantes derechos humanos....

Entendemos que el proceso de homologación es un verdadero proceso contencioso pues concurre un interés público superior en el Estado que debe protegerse como en ambas partes demandante y demando. Y por cuya virtud cabe oposición a través de los órganos establecidos por el Estado que actúan como partes pasivas en ese proceso de reconocimiento oponiéndose o conformándose, así como quien se oponga al reconocimiento u homologación. Aunque en la mayor parte de los casos la no oposición vaciará toda forma contenciosa externa y en este aspecto su estructura se puede asemejar a la actividad de la jurisdicción voluntaria.

Además, es el medio para que la sentencia extranjera una vez reconocida alcance los efectos de cosa juzgada sin olvidar que la cosa juzgada es inmanente al proceso nacional. Art. $117 \mathrm{CE}$. Incluso en caso de que por un Acuerdo Internacional con la Unión Europea se exima a la sentencia extranjera de reconocimiento ello supone que, sin más o automáticamente, en su virtud adquiere el carácter de cosa juzgada como si fuera una sentencia nacional.

La cosa juzgada en cuanto manifestación de la jurisdicción (art. $117 \mathrm{CE}$ ) tiene - junto a los límites subjetivos referidos a las partes siempre dependiendo de su situación concreta en un proceso; los objetivos referidos al petitum y causa petendi (que varían según el proceso de declaración sea plenario o sumario, y de que en el plenario se permita o prohíba el goteo de las causas petendi que fundamentan la pretensión); los temporales (cambio de la norma material aplicada por sucesión ulterior normativa, o alteración sobrevenida en la situación material del proceso, o respecto a las garantías procesales incumplidas que originen indefensión al justiciable como en caso de la rebeldía involuntaria que dé lugar a un proceso de audiencia al rebelde o del proceso de revisión....) - un límite espacial. 
Ese límite espacial coincide con la Soberanía del Estado, con el ámbito del poder judicial y de su función jurisdiccional, es decir la cosa juzgada como manifestación de la jurisdicción coincide con el ámbito espacial de la jurisdicción (117 CE), el de la Soberanía del Estado y por ello el juicio de reconocimiento u homologación de sentencias extranjeras opera como tal límite al estar fuera de ese ámbito - salvo que por tratado internacional sea innecesaria esa homologación y se le reconozca sin más a la sentencia extranjera la cosa juzgada y la propia «jurisdiccionalidad» que conlleva tal sentencia.

En el ámbito de la jurisdicción voluntaria puede seguirse un procedimiento de esta especie en España para obtener una resolución de este carácter, en el que deba probarse el derecho extranjero para que sea aplicado en dicho auto; o que se tenga que reconocer u homologar un acto de jurisdicción voluntaria dictado en otro país es decir la resolución extranjera que tenga carácter de jurisdicción voluntaria. (A ello se refieren la vigente Ley de jurisdicción voluntaria y la Ley de Cooperación jurídica internacional en materia civil).

Su naturaleza jurídica en estos casos será también de jurisdicción voluntaria (al no existir partes si no un único solicitante (lo componga un único sujeto o sean varios) y el juez, secretario judicial, notario e incluso el registrador), aunque algunos de estos expedientes también afectan a los intereses públicos del Estado que deberá protegerlo o hacerlos valer a través de sus órganos que ostentan la legitimación activa o pasiva (así el Ministerio Fiscal, Abogado del Estado, quienes puedan asumir la defensa de consumidores o usuarios o personas de otro tipo que dispongan de legitimación extraordinaria) cuando estos trascienden el mero interés privado.

En ambas manifestaciones, hasta ahora abordadas, el Estado renuncia en este aspecto y en cierta medida a parte de su Soberanía Nacional. Renuncia a aplicar, en su territorio, sus propias leyes o normas materiales nacionales (es decir, a la territorialidad de sus normas materiales) y aplica o reconoce (homologando) las extranjeras (de concurrir un elemento de extranjería que lo justifique) en aras de la cooperación jurídica internacional, en aras del comercio internacional, en aras del respeto a la condición jurídica de la extranjería, o...

Pero sólo en favor y dentro del ámbito exclusivamente permitido por el derecho material privado extranjero (salvo acuerdos o tratados internacionales suscritos por España referidos a la aplicación - aquí- del derecho público o penal extranjero) referido a derechos civiles, mercantiles o laborales del contrato de trabajo disponibles e incluso cuando son indisponibles (así la capacidad de las personas 
extranjeras y manifestaciones del derecho de familia extranjero) que sería entonces aplicable en España (o reconocido y homologado aquí).

Queda fuera, como decimos, (salvo Acuerdo o Tratado Internacional de España con otros países) el ámbito del derecho público extranjero, que no es aplicable en España (salvo la excepción dicha) y respecto al cual se aplica el derecho nacional material vigente en cuanto afecta a los intereses generales, el cual sólo será aplicable en el proceso y en el orden jurisdiccional que corresponda (penal o contencioso administrativo) como se establece en el art. 8 CC (en términos decimonónicos al referirse a las leyes penales, de policía, seguridad pública) o en otras normas nacionales especiales (leyes administrativas de todo tipo, fiscales, militares).

Y las normas procesales nacionales se aplicarán siempre en España para la actuación de esos derechos (a salvo de Tratado Internacional en contrario, que obligue a la aplicación en España de normas procesales extranjeras, con carácter excepcional, Art. 3 y 4 LEC y 96 y ss. CE). En este sentido, todos estos supuestos y ámbitos (administrativo, fiscal, procesal, militar -incluso dentro o fuera de las bases o destacamentos militares extranjeros como podían ser antes Torrejón de Ardoz y hoy Rota-) supondrán un límite a nuestra Soberanía Nacional (Art. 96 y ss. CE), de aplicarse en España el derecho público extranjero, en aras de esa cooperación jurídica internacional, sobre todo dentro de la Unión Europea.

Como decíamos al inicio, una u otra opción son manifestaciones extremas y por ello susceptibles de graduación. Negar la extranjería y todo tipo de derechos a los extranjeros por el Estado a través de sus normas supone colocar a los extranjeros en situaciones extremas de desprotección con lo que acabarían marchándose del país en que se encuentran, o por el contrario no emigrarían a éste. Podrían llegar a tener una situación semejante a la de las clases serviles en la Edad Media.

Por el contrario, el Estado puede reconocer los mismos derechos privados e incluso algunos derechos públicos (estos últimos, más limitados a los extranjeros por carecer de nacionalidad y las obligaciones que conlleva esta situación) a los extranjeros en la misma forma o de forma parecida que a los nacionales.

O negarles algunos y que los negados sólo puedan corresponder a los nacionales, así el ejercicio de ciertas actividades comerciales o industriales (en este caso fundándose en una política proteccionista de la economía nacional o al menos desde el plano fiscal fun- 
dándola en una política arancelaria que las limite a extranjeros) lo cual fue muy frecuente en España y Europa durante la Edad Media y Moderna, como recogían las Partidas y las Leyes de Recopilación). Los derechos públicos siempre estuvieron muy limitados a los extranjeros. Véase para nuestro derecho histórico el régimen jurídico de los extranjeros, los judíos y los moros, en Álvarez-Valdés y Valdés en su obra «La extranjería en la historia del derecho español».

Como decíamos cuando el Estado reconoce derechos a los extranjeros éstos pueden ejercitarlos de la misma forma que los nacionales de acuerdo con la Ley del foro y ante los tribunales nacionales que se declararían competentes cuando su sentencia puede ser ejecutada en dicho Estado partiéndose de que el demandado tenga domicilio o residencia en el país del foro, o al menos tenga en él bienes, sobre todo raíces, es decir inmuebles para hacer efectiva su posible condena al pago de una suma en dinero o una condena de otra especie susceptible de convertirse en ejecución dineraria.

Actualmente - no así en la Edad Media y en la Moderna- esa política restrictiva de derechos al extranjero se consideraría una clara manifestación de política «ultramontana» en defensa de la economía nacional y por ello de los nacionales e incluso se podría considerar vulneradora de derechos fundamentales en cuanto suponga una discriminación personal al extranjero. Es incompatible con las directrices de la política económica de la Unión Europea.

Finalmente, el Estado puede reconocer estos derechos a los extranjeros en régimen de igualdad con los nacionales sobre todo en el ámbito del derecho privado civil y mercantil como ocurre en la actualidad y su origen arranca de las políticas liberales iniciadas desde el primer tercio del S. XIX en la Europa de nuestro entorno.

$\mathrm{Y}$ en este caso permitir que los extranjeros actúen sus derechos conforme a la ley del foro (sistema seguido en España hasta el segundo tercio del S. XIX). O conforme a la ley nacional extranjera en el ámbito privado si se refiere sobre todo a cuestiones atinentes a su estatuto personal o al del lugar y la forma de la consumación del contrato (sistema seguido en España a partir del tercer tercio del S. XIX en virtud de la doctrina legal creada por el TS al pronunciarse en los recursos de casación por infracción de ley (y doctrina legal) y consagrado legalmente por el CC de 1888-89).

Así se establece que los extranjeros pueden acudir a los tribunales nacionales para defender sus derechos según la norma extranjera que determina la norma de conflicto nacional. (Art. 9 a 12 CC, y leyes es- 
peciales). Por tanto, en este último caso en clave conflictual como dicen los estudiosos del derecho internacional privado.

La Ley del Estado en cuestión determina pues, en qué casos los extranjeros se regirán por la norma extranjera que será la aplicable una vez probada - conforme a la denominada norma de conflicto a la que remite (existe nutrida tipología y no es objeto de este trabajo examinar su clasificación)_; y cuando y en todo caso se rigen por la nacional o del foro (art. $8 \mathrm{CC}$ y leyes especiales). Y para que ello sea efectivo parece lógico que la norma de conflicto, si el objeto es indisponible, sea imperativa para que pueda ser aplicada de oficio por los Tribunales (art. $12 \mathrm{CC}$ ) a salvo que sea disponible y que previa exclusión voluntaria de la de conflicto, art. 6-2 CC, en documento y antes del inicio del proceso pueda ser aplicada otra norma material específica.

Si fuese enteramente dispositiva (y sin una exclusión previa y voluntaria consensuada entre los contratantes en favor de otra), quedaría en manos del demandante optar por la extranjera o la del foro con el consabido perjuicio al demandado, salvo que previamente al proceso exista un acuerdo previo entre las partes en el que renuncian, es decir excluyen voluntariamente (art. 6-2 CC) la aplicación de la norma de conflicto.

Exigir el acuerdo mutuo de demandante y demandado para la aplicación de la norma de conflicto iniciado el proceso, sería muy difícil entre las partes (en especial si es muy diferente el régimen jurídico entre las distintas normativas que se desean aplicar (v.gr. del foro y extranjera). $\mathrm{O}$, aunque sean semejantes, sean diferentes - cualitativa o cuantitativamente- los efectos jurídicos de las leyes que una u otra parte desea se apliquen y que en la mayor parte de los casos la falta de acuerdo de ellos llevaría, o a la aplicación de la lex fori con lo que la norma de conflicto quedaría desvirtuada, o a la aplicación de la de conflicto que operaría como norma imperativa.

Por lo tanto, es la Ley nacional del Estado o la del foro la que reconoce la extranjería y los derechos a los extranjeros. Es esta Ley nacional del Estado o del foro la que reconoce o niega la existencia del mismo derecho internacional privado estableciendo los fueros de la competencia «internacional» civil que no son propiamente normas de atribución de competencia objetiva o territorial a nuestros tribunales, si no normas de atribución o exclusión (a sensu contrario) de la jurisdicción y por ello de la atribución de la competencia nacional al orden jurisdiccional civil (Art. 21 y ss. LOPJ) de nuestros tribunales cuando existe un elemento de extranjería. 
De la misma forma que es la ley nacional la que determina a través de la norma de conflicto en que supuestos nuestros tribunales deben fallar, en la sentencia, aplicando el derecho extranjero o el nacional del foro.

Cuestión distinta es que a través de los diferentes sistemas de derecho comparado y en virtud de los Convenios o Tratados internacionales bilaterales o multinacionales se pueda construir la ciencia del derecho internacional privado, repito, sobre la base del derecho comparado. Fuera de esto, es el derecho nacional quien determina el régimen del así «denominado» derecho internacional privado.

Sin embargo, fuera de los tribunales (proceso o jurisdicción voluntaria) si la materia es disponible (estemos ante el cumplimiento voluntario de las obligaciones, la autodefensa cuando se permite, la autocomposición — previa mediación o conciliación, como en la transacción, o en la heterocomposición del arbitraje), lo señalado en párrafos anteriores queda desvirtuado. Se aplica el derecho que voluntariamente cumplen las partes o las consecuencias jurídicas que determinan estos sistemas de solución de conflictos alternativos al proceso, coincidan o no las mismas con las establecidas en la norma de conflicto que remite a la ley del foro o a la ley extranjera.

Me pareció conveniente partir de los párrafos que anteceden, para entrar ahora en los distintos periodos de nuestro derecho histórico para su mejor comprensión.

De todas formas, nuestra historia puede resumirse en dos periodos:

a) El primero va desde los inicios (siempre conocidos fragmentariamente) de nuestra historia legal hasta la segunda mitad del S. XIX, y ponemos dos fechas bastante aproximadas como momento final del primer periodo y de inicio del segundo.

1855, es la fecha de la primera LEC que permitió el reconocimiento, homologación o «exequatur» en España de las sentencias dictadas en el extranjero en las que se aplicaba una norma extranjera para que pudiera tener efectos en España. Su simple reconocimiento (sentencias de mera declaración o constitutivas y estas susceptibles o no de inscripción en registros públicos) o ser reconocidas para después ser ejecutadas aquí (propio exequatur si se hace derivar la palabra latina al proceso de ejecución de pretensiones declarativas de condena). 
1864 que es la fecha de la primera STS, que conocemos, que admite que se puede aplicar el derecho material extranjero en España, una vez probado, por nuestros jueces y tribunales.

Por lo tanto, en este primer periodo, al que me referí en cuanto a su momento inicial y final sólo se aplica por nuestros tribunales de la jurisdicción ordinaria estatal (que es la civil) en el ámbito de las pretensiones civiles la ley nacional o la del foro. Fuera de los Tribunales, y respecto a los medios alternativos al proceso estar a lo ya dicho.

$\mathrm{Y}$ en las pretensiones mercantiles se aplica el régimen convencional pactado en los contratos mercantiles y en su defecto la legislación del foro material mercantil (Libro del Consulado del Mar, Ordenanzas de Bilbao, disposiciones dispersas en múltiples reales cédulas así como una jurisprudencia consular de carácter consuetudinario y después el C de C de 1829) por la jurisdicción mercantil, especial y privilegiada Consular y según las normas procedimentales del proceso consular (recogidas en el Libro del Consulado del Mar, Ordenanzas de Bilbao y desde 1830 en la Ley de Enjuiciamiento de negocios mercantiles).

Por lo tanto, se aplica la ley del foro por nuestros jueces y Tribunales a los derechos civiles o mercantiles (salvo pacto específico muy habitual en este ámbito) reconocidos a los extranjeros de la misma forma que a los nacionales.

b) Y desde las últimas fechas. Así 1855 en que la LEC permite el reconocimiento y ejecución de las sentencias extranjeras en las que se aplicó el derecho extranjero (sea el civil y mercantil, aunque respecto al mercantil el Decreto de Unificación de fueros es de 1868 para que conozca de su reconocimiento el TS, suprimida la jurisdicción consular).

Y desde 1864 en que la doctrina legal de nuestro TS a través de su jurisprudencia colma la laguna legal permitiendo que nuestros Jueces y Tribunales puedan aplicar a extranjeros incluso nacionales (en las sentencias civiles -y después mercantiles desde 1868 tras el Decreto de Unificación de fueros-) normas de derecho extranjero una vez probadas creando jurisprudencialmente la norma nacional de conflicto que remite a la extranjera de su estatuto personal (civil), la del lugar de consumación de los contratos civiles o mercantiles o las referidas a la regulación de la forma de su celebración. Y estableciendo jurisprudencialmente los requisitos de la prueba de ese derecho extranjero. 
No se olvide que en ambos casos estamos ante las dos caras de una misma moneda que es la aplicación del derecho extranjero de forma directa por los tribunales nacionales, aunque variando el momento. Aplicar el derecho extranjero — una vez probado- por los tribunales del foro en los procesos ventilados en nuestro país en la sentencia de primera o ulterior instancia. Desde esa jurisprudencia civil del TS iniciada en 1864 y que alcanza el carácter de doctrina legal a partir de su segunda sentencia y que desde 1868 se aplica directamente a lo mercantil por el Decreto de Unificación de Fueros.

Aplicación indirecta por reconocimiento u homologación desde la LEC de 1855 en pretensiones civiles, donde los tribunales extranjeros aplican las normas extranjeras (del foro o de otro país) en sus sentencias y que para que tengan efectos en España debían ser reconocidas dichas sentencias por nuestro TS en aquel momento (sin perjuicio de convenios bilaterales ulteriores) y que desde 1868 se aplicó a las mercantiles por el Decreto de Unificación de Fueros al desaparecer la jurisdicción mercantil especial consular y derogarse la Ley de Enjuiciamiento de Negocios de Comercio de 1870 y sus disposiciones pasaron a aplicarse (o a formar parte) dentro de la LEC 1855 hasta que la LEC 1881 las refundió en un único cuerpo legal. No conozco que se solicitara el reconocimiento de sentencias mercantiles extranjeras de 1864 a 1868.

\section{DERECHO ROMANO}

Poco sabemos de la situación jurídica existente de los pueblos que poblaban la península Ibérica antes del año 218 AC, en que llegaron los Romanos. Sabemos que muchos pueblos habían sido vencidos y conquistados años antes, cuando llegaron los Cartagineses por no haber sido sumisos con la conquista o porque mantenían lazos comerciales con Roma enemiga de Cartago.

Según los romanistas el derecho privado romano era el único aplicado por sus jueces en las contiendas entre los romanos. A los extranjeros o «peregrinos» se les aplicaba el «ius Gentium» que era igualmente derecho romano. Y su aplicación por el Pretor Peregrino lo era muchas veces con grandes dosis de «equidad» para proteger sus derechos a través del «ius Gentium». Buscaba el Pretor en su decisión el consenso entre los litigantes en materia de derecho privado disponible. Por esto se trataba de una jurisdicción especial para ciertas materias o ámbitos jurídicos de derecho privado incluido el comercial, 
entonces sin autonomía. Jurisdicción, por ello de carácter privilegiado y personalista para los extranjeros en defensa de sus derechos privados.

Otorgada la ciudadanía a todos los residentes en el Imperio Romano por el Edicto de Caracalla, el año 212 (por razones fiscales para que los extranjeros - junto a los romanos-sufragaran el costo de las campañas militares), dejó de tener sentido el «Ius Gentium», su jurisdicción y el cometido del «Pretor Peregrino», fundiéndose el «Ius Gentium» con el Romano. Desapareciendo así esta jurisdicción «especial» y su Pretor "Peregrino» y refundiéndose en la ordinaria.

Si fue así, no podemos olvidar que junto a los extranjeros denominados peregrinos a los que se aplica el «Ius Gentium» y a los ciudadanos romanos a los que se aplicaba el derecho romano, estaban los habitantes de las provincias del Imperio Romano entre las que se encontraba Hispania.

Tampoco se debe olvidar que, durante la conquista de Hispania por los Romanos los pueblos que fueron sumisos y pacíficos solían llegar a acuerdos de futuro con los conquistadores cuyo objeto era el respeto del derecho autóctono de sus pobladores (privado e incluso público) sin olvidar que algunos pueblos de la península ya antes de la conquista romana eran aliados de Roma por haberse enfrentado a Cartago o por sus relaciones comerciales previas con los conquistadores. De lo que no parece haber duda es que con el paso del tiempo el Derecho Romano se impuso pacífica o forzosamente en los pueblos de nuestra península y que el Derecho Romano, siempre en completa expansión, tomó para sí — también- manifestaciones jurídicas de los pueblos conquistados.

\section{DERECHO VISIGÓTICO}

El año 409 y los inmediatos que siguen, la península Ibérica es ocupada por diversos pueblos denominados bárbaros o genéricamente godos sobre la base de su procedencia (Alanos, Vándalos, Suevos, Visigodos). Los dos primeros estuvieron poco tiempo en la península trasladándose a otros lugares o fusionándose con los últimos. Los suevos se establecen en el S. v en Galicia, pero en el siglo posterior son vencidos por los visigodos.

Por lo tanto, los visigodos en el S. vi habían conquistado la Península y tenían su control político y militar. Lo que ocurrió en el siglo v y vi hasta la total conquista de la península por los visigodos 
es un enigma histórico, aunque es muy posible que respetaran el Derecho Romano privado de los habitantes autóctonos y el Derecho se estableciera sobre una base personalista que poco a poco se fue convirtiendo en territorial. Desde la conquista total de la Península se impone el derecho a todos los pueblos consiguiendo que el derecho establecido al ciudadano autóctono se convierta en el derecho de ámbito territorial aplicable a toda la Península y sus habitantes, en especial desde la unidad religiosa que pasó a ser la religión católica del Estado.

La discusión sobre la personalidad o territorialidad del derecho puede tener sentido en el S. v y VI. Conquistada toda la Península y en virtud de su unificación política y religiosa el Derecho se aplica sobre la base de la territorialidad a todas las personas.

De todas formas, la posible aplicación dual de un Derecho personalista en un primer momento, S. V y vi (un derecho para las personas autóctonas de la península y otro para los nuevos conquistadores) desde finales del S. VI pasa a ser territorial y común a todos los habitantes de la península Ibérica. (Señalamos como fecha relevante del paso o sucesión de un periodo a otro el año 586 fallecimiento del rey Leovigildo y el 587 que se produce la conversión de su hijo Recaredo al catolicismo y sobre todo desde la unificación nacional religiosa por la influencia posterior que tuvieron sobre el Derecho nacional los Concilios religiosos de Toledo).

La dualidad de derechos, base de una aplicación personal a los habitantes autóctonos y a los visigodos conquistadores y su posterior territorialidad para aplicarse a todos sobre la base de la unidad política, jurídica y religiosa en la península Ibérica hará surgir la conciencia de Nación en sus habitantes y el sentimiento de un Estado central. Nada tiene que ver esto con la extranjería y los derechos limitados de los extranjeros a los que se aplica el Derecho nacional o foráneo. Personalidad y luego territorialidad del derecho para conquistadores y conquistados. Muy pocos derechos y de contenido muy limitado para los extranjeros a los que se aplica el derecho del foro.

En este sentido y respecto al extranjero La Lex Romana Visigotorum o Breviario de Alarico (hacia el año 506) siguiendo a ÁlvarezValdés Valdés estableció fuertes límites a los derechos de los judíos equiparándolos a los de los extranjeros. Derechos que se prohíben a judíos y silencia respecto a extranjeros (prohibición de poseer esclavos cristianos, contraer matrimonio con católicos, persecución del proselitismo religioso no católico, prohibición de convertirse al judaísmo los que no hebreos de origen ...). 
De la misma forma, el Liber Iudiciorum (hacia el 653-54) o Lex Visigotorum también denominado en su acepción vulgar Fuero Juzgo impuso fuertes restricciones a los derechos de los extranjeros y judíos (así prohibición de hacer Rey a un extranjero; tener esclavos de cierta condición; dedicarse a actividades mercantiles, oficios industriales o a la usura; el proselitismo religioso no católico) aunque también dictó normas protectoras del extranjero (el juez debe proteger y defender al extranjero...).

En lo que concierne a la admisibilidad de la aplicación de la ley extranjera en los juicios seguidos ante nuestros tribunales en su Libro II, Título I, Ley VIII establece que no se aplicarán en los juicios seguidos ante nuestros jueces las leyes extranjeras, ni las del Derecho romano; en concordancia con ello la Ley IX del mismo libro y título establece que no se presenten al juez otros libros de Leyes que no sea éste. Y según la Ley XI del mismo libro y título el Juez sólo puede juzgar dentro de su competencia, es decir, en caso de extranjería conforme a la ley del foro cuando el demandado puede cumplir la sentencia o ser ejecutado. (Fuero imperativo y exclusivo de competencia para los extranjeros ligado al posible cumplimiento y ejecución de la sentencia).

Este texto es muy importante pues supone el inicio en nuestra tradición histórica legislada del régimen de la aplicación exclusiva en el proceso seguido en España, de la lex fori o nacional en las contiendas entre extranjeros entre sí o de estos con nacionales cuando existe un elemento de extranjería que se mantendrá invariable en otros textos posteriores hasta mediados del S. XIX. Según esta tradición jurídica nuestro derecho histórico nacional en lo sucesivo mantuvo que no se aplicasen en los juicios seguidos ante nuestros jueces, las leyes extranjeras. Y por esta razón no se podía alegar el derecho extranjero, ni fundamentar en éste la demanda o la contestación a ésta.

Por ello el derecho extranjero no puede ser alegado, ni fundamentado, ni ser objeto de prueba su existencia, vigencia, contenido y alcance, al no poder ser aplicado por el Juez nacional del foro. Y esta tradición histórica que establece la prohibición de aplicar el derecho extranjero se mantiene invariable desde el Liber Iudiciorum hasta la segunda mitad del S. XIX, como decíamos.

No llegó a durar tanto tiempo esta prohibición respecto a la alegación y aplicación de derechos que no eran nacionales (en el sentido de reales) como eran el Derecho Romano y Canónico, pues como veremos respecto a ellos se levantó la prohibición de alegarlos y fundamentarlos al poderse aplicar — ambos- desde el S. XIV en los pleitos 
civiles seguidos ante la jurisdicción real ordinaria. Aunque no cabía su aplicación directa, si cabía la indirecta en cuanto formasen parte de la interpretación doctrinal considerada auténtica de ciertos jurisconsultos posglosadores que aparecen mencionados en textos legales, que examinaré posteriormente. (Además tampoco se exigía la prueba, de dicha doctrina romanista o canonista que se daba por válida).

Recalco de nuevo, me refiero al derecho romano y canónico aplicado en pleitos civiles (incluso el canónico a instituciones procesales, como la sentencia) ante la jurisdicción real ordinaria. Es obvio que en la jurisdicción eclesiástica sí que se aplicaba el derecho canónico.

Finalmente, el Libro II, Tít. I, Ley IV limitaba en cierta medida el principio de la territorialidad de la ley en favor de la costumbre si es praeter o secundum legem, al establecerse que se debe guardar la ley según la costumbre de la ciudad.

\section{LA CAÍDA DEL ESTADO VISIGÓTICO Y ALTA EDAD MEDIA}

El año 711 el ejército hispano-godo o visigodo es derrotado en la batalla de Guadalete por los musulmanes mandados por Tarik (y después también por Muza) desapareciendo en la batalla el último rey visigodo, Rodrigo. Pocos años después, los musulmanes dirigidos por los mismos Tarik y Muza bajo las órdenes del Califa de Damasco habían conquistado prácticamente toda la península Ibérica perdiéndose definitivamente la unidad política, jurídica y religiosa de la España visigoda, que no se recobró hasta muchos siglos después.

Esto es importante dado que el concepto de extranjero, perdida la unidad y la conciencia nacional toma otra consideración. Extranjero ya no es la persona que no es de la península Ibérica y que es ajena a esa unidad política, jurídica y religiosa. Si no el que no es oriundo de la ciudad, o de la tierra que la limita o circunda, o de los pequeños reinos en expansión que se irán formando, aunque dicho extranjero sea - en origen - hispano. Para equiparar la condición de ese particular "extranjero» con la de los autóctonos del lugar se dictan durante la Alta Media multitud de Fueros y Cartas de Población cuyo objeto es la equiparación de los derechos de los lugareños y los que no lo son y sobre estos Fueros y Cartas de Población no entraré al no ser objeto de este trabajo. Se aplicaba a todos, según el Fuero, el derecho de la tierra (o territorio), según la costumbre del lugar.

Esta situación se mantendrá hasta la Baja Edad Media, época en que las grandes conquistas de los Reyes cristianos se extienden a gran 
parte del territorio de la Península Ibérica y donde destacan los Reinos y las Coronas de Castilla (unificados los reinos de Asturias, Galicia, León, Murcia y los territorios vascos incorporados a la corona de Castilla), de Aragón (Aragón junto al Condado de Cataluña y los Reinos de Valencia, Baleares y territorios extra peninsulares de Nápoles y Sicilia) y Portugal a través de los cuales se buscará la futura unidad jurídico política.

Ayudará a esa unidad jurídica la recepción del Derecho Romano o común que se manifiesta en el texto de las Siete Partidas, aunque dicha unidad jurídica no se conseguirá plenamente hasta el S. XIX con la codificación, y a la que se refiere por primera vez la Constitución de Cádiz de 1812, es decir a unos códigos comunes que se apliquen en toda la península. La unidad política no llegará hasta la unión de las dos Coronas en la persona de Carlos I y después Felipe II, pero conservando tales Reinos (incluido el del Portugal que poco después se pierde definitivamente en 1640) una gran autonomía hasta el S. XVIII. Igualmente, los Decretos de Nueva Planta de Felipe V supusieron un avance en la unidad política y jurídica. En esta unidad jurídica y política de nuevo el papel de la Iglesia Católica, desde el S. XIII, es fundamental.

\section{LA BAJA EDAD MEDIA Y LA DOCTRINA ESTATUTARIA EUROPEA}

Es importante señalar que a comienzos del S. XIII en las Repúblicas Italianas (lo que destacamos, antes de entrar en nuestros textos legales de la Baja Edad Media), surge un movimiento jurídico o corriente doctrinal denominado los Estatutos o Estatutaria, y Estatutarios sus seguidores. (Se considera el precedente más próximo del moderno Derecho Internacional Privado).

Según este movimiento jurídico o corriente doctrinal, para solucionar en el proceso los conflictos jurídicos entre las partes - siempre que exista un elemento determinante de extranjería- procede la aplicación del derecho extranjero al caso concreto siempre sobre la base de una norma de conflicto - $\mathrm{O}$ de no existir, en clave conflictualdonde el concreto estatuto (de ahí su denominación) remite a la norma extranjera aplicable y puede ser personal (el las personas) entendiendo como tal su nacionalidad; real o el estatuto de las cosas (muebles o inmuebles, según su situación); o el estatuto convencional o del lugar de la celebración de los contratos y sus formas. Y no se aplicaría entonces la ley del foro, en clave de extranjería. 
Su iniciador - por lo que fragmentariamente conocemos o sabe-

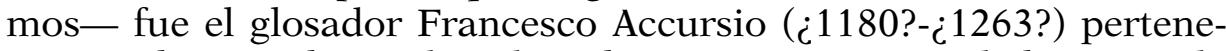
ciente a la Escuela jurídica de Bolonia y que es autor de la conocida como Magna Glossa (Gran Glosa ¿1227?).

Según este movimiento si una persona se va de su país o ciudad, a otro-a «lleva consigo su estatuto personal» o «la norma jurídica del país o ciudad de origen» por la que debe regirse y por ello en el nuevo país se le debe permitir que se rija por ésta en sus relaciones personales de derecho privado, sin estar obligado a regirse por la norma reguladora del país del foro.

Lo contrario impediría o limitaría las relaciones personales y comerciales entre los países y las ciudades, pues las personas se negarían - por esto- o se pensarían mucho trasladarse de su país o ciudad de origen a otro-a. Surgen así los Estatutos para el extranjero de los que el más importante es el personal (capacidad, familia, régimen familiar y económico del matrimonio, sucesión...), pero también destaca el real (situación de los bienes muebles e inmuebles) y el contractual y el de sus formas que es la base de los contratos.

Es importante destacar que Francesco de Accursio, tuvo una gran influencia en el derecho italiano del momento e incluso en los países europeos limítrofes convirtiéndose en una de las figuras más sobresalientes del movimiento glosador y estatutario. Influyó también como glosador, doctrinalmente, en la recepción en España del Derecho común romano, a través del texto de las Partidas. Sin embargo, la doctrina Estatutaria apenas tuvo cabida en las Partidas (existen supuestos especiales muy limitados) ya que éstas mantuvieron la tradición de la territorialidad en la aplicación del derecho nacional o del foro para todas las personas.

\section{LA BAJA EDAD MEDIA ESPAÑOLA A TRAVÉS DE SUS TEXTOS JURÍDICOS}

Textos jurídicos nacionales de la Baja Edad Media. Merecen destacarse:

a) FUERO REAL. (Hacia 1252-55). Establece la obligatoriedad y exclusiva territorialidad en la aplicación de sus normas y su supletoriedad respecto a otras leyes. Se fijan normas específicas referidas a los derechos de los extranjeros y fuertes restricciones en los derechos de los judíos (hebreos) y musulmanes (a los que denomina moros) como si fueran extranjeros, así como la prohibición a los cristianos de 
convertirse a estas religiones. Línea que se mantendrá en el Espéculo redactado años después y precedente de las Siete Partidas.

b) CÓDIGO DE LAS SIETE PARTIDAS. (Hacia 1260). Mantiene la tradición del Fuero Juzgo sobre la base de la territorialidad de las leyes materiales y procesales que se aplican a todos, sean del Reino o extranjeros. Así en la Partida I, Título I, Ley XV (Como deben obedecerse las leyes y juzgarse por ellas). Y en la Partida III, titulo XIV, Ley XV. (Como se pueden probar los pleitos por la ley material y procesal). Aunque se sientan algunas excepciones permitiéndose en ciertos casos la aplicación personal de algunas leyes materiales, aunque ello suponga una situación de privilegio para esas personas.

También se mantienen las restricciones y prevenciones para los musulmanes a los que denomina «moros» y a los hebreos que denomina «judíos».

Es una obra doctrinal que no fue sancionada como norma legal en el momento de su nacimiento, pero que alcanzó suma importancia pasando a ser fuente supletoria desde el S. XIV y en la realidad jurídica operaba como fuente directa. Tuvo gran influencia no sólo en el Reino de Castilla, con la que se recepcionó el derecho común, si no en el resto de los Reinos de la Península y a partir del S. XVI en la América Hispana.

c) CUERPOS LEGALES POSTERIORES. No alteran la situación del principio de territorialidad. Así las Leyes de Estilo (principios del S. XIV) que se refieren a interpretaciones, aclaraciones y advertencias sobre usos y observancias judiciales en los procedimientos contenidos en las leyes del Fuero Real.

De igual forma, el Ordenamiento de Alcalá (1348) aprobado por las Cortes reunidas en dicha ciudad y año. El Fuero Viejo de Castilla (1356) recopilación privada del derecho medieval castellano realizada en tiempo de Pedro I aunque existe un texto anterior del S. XIII. Las Ordenanzas Reales de Castilla recopiladas por Díaz de Montalvo (1484), de ahí su sobrenombre de Ordenamiento de Montalvo que es la primera Recopilación hecha del derecho castellano.

Tampoco alteran el principio de la territorialidad de las normas Las 83 Leyes de Toro, disposiciones de los Reyes Católicos que se publican bajo el reinado de la Reina Juana (1505); ni La Nueva Recopilación de las Leyes de estos Reinos hecha bajo Felipe II y publicada en 1567. 
Es conveniente destacar que la territorialidad de estas leyes suponía que su aplicación lo era tanto para ciudadanos o súbditos según terminología del momento del Reino de Castilla; para los de la corona Aragón, incluso tras la unión de ambas coronas, muerto Fernando V, en su sucesor Carlos I. Y para los extranjeros. La misma situación ocurría en el Reino de Aragón. La unidad jurídica prácticamente no se consigue hasta mucho después sobre todo en el S. XIX sobre la base de la Constitución de Cádiz de 1812 (unos mismos códigos regirán en todo el reino) y sobre todo con la codificación comenzada en 1822 (se inició con el derecho penal) y terminada en 1888-89 (para el derecho civil común general), aunque los Decretos de Nueva Planta a comienzos del S. XVIII tendieran a dicha unidad.

d) DISPOSICIONES ESPECIALES. Debo también destacar disposiciones dictadas desde fines del S. XIV en pro de la territorialidad del Derecho castellano y en contra de la aplicación del derecho extranjero.

En efecto en las Cortes reunidas en la ciudad de Briviesca en 1387, se confirma la prohibición de aplicar el derecho extranjero con la salvedad del Derecho Canónico y Romano (en la jurisdicción civil ordinaria y tratándose de la doctrina auténtica de ciertos jurisconsultos que eran romanistas o canonistas y que se señalan). No se consideran ambos derechos, extranjeros, a los efectos de este régimen jurídico. (Remito a lo ya dicho en el Fuero Juzgo de la prohibición de aplicar las leyes romanas).

Igualmente, destacar que el derecho canónico quizá no se consideró extranjero (a los efectos de su aplicación en la jurisdicción ordinaria civil) quizá por su universalidad y unidad en todos los lugares en que se aplica; como tampoco el romano, aunque se tratase de aplicarlo como «ius commune» y que éste se recepcionó en el texto de las Partidas y por tanto el contenido de las Partidas no tenía la condición de derecho extranjero si no de nacional pese a su supletoriedad, y carácter privado en cuanto norma que no fue promulgada como tal. Ello sin olvidar que en las Universidades desde el S. XIII en la Licenciatura de Cánones y Leyes solo se estudiaba el derecho canónico y el romano y no el derecho vigente también llamado Real, aplicado por la jurisdicción real u ordinaria.

Dicha prohibición de alegar y probar el derecho extranjero fue confirmada en las Cortes reunidas en Segovia en 1390 y en Madrigal en 1476. La Pragmática de Juan II de 1427 permitió que en las demandas y su contestación se hicieran alegatos jurídicos de Derecho Romano y Canónico en pleitos civiles de forma indirecta siempre que 
formaran parte de la doctrina «auténtica» de los juristas Bártolo y Baldo respecto al derecho romano no permitiéndose sin embargo realizar alegatos jurídicos que fueran doctrina de otros juristas diferentes, ya glosadores o posglosadores.

Igual aconteció con la doctrina jurídica, considerada auténtica, de ciertos canonistas que aparecen señalados cuando este Derecho canónico podía aplicarse por los jueces de la jurisdicción real ordinaria en materias temporales y fuera del ámbito de la jurisdicción eclesiástica. Lo cierto es que el derecho Romano y Canónico sin ser Derecho nacional o Real no eran tampoco considerados - propiamente- derechos extranjeros, aunque lo fueran en su origen al provenir de Italia o del Vaticano.

Estas disposiciones fueron confirmadas en las Cortes de Valladolid de 1485 y en las Ordenanzas de la Chancillería de Valladolid de 1489 como por las Ordenanzas de la Chancillería de Granada, en 1494. Además, en las Cortes de Madrid de 1499 fueron aprobadas las denominadas «Leyes por la brevedad y orden de los pleitos» que buscaban agilizar el proceso común ordinario (también denominado «solemnibus ordibus iudiciarum in totius tempus» que traduzco libremente como «solemne orden de los juicios en sus respectivos tiempos»), excesivamente lento y sometido a todo tipo de dilaciones irregulares y que constituyó el verdadero problema procesal de Castilla durante muchos siglos. Estas leyes fueron confirmadas por las Ordenanzas de Madrid de 1502 y después por las Cortes de Alcalá de Henares en 1503 y las de Segovia de 1532.

$\mathrm{El}$ «remedio» propuesto era la concisión en los alegatos fácticos y jurídicos de la demanda (que cuando se publicaban constituían los porcones) o de su contestación concretándose ambos a los hechos y alegatos jurídicos fundados en normas nacionales precisas (fundamentación) evitando la extensión y reiteración sucesiva de los mismos alegatos en posteriores escritos; mayor control sobre los plazos en especial en los extraordinarios de la prueba; control de los escritos en que se solicitaba a instancia de parte la impulsión del proceso y mayor concisión en los escritos de alegación de bien probado (hoy llamados de conclusión oral del acto del juicio).

Lógico parece entender que ante la situación de excesiva dilación del proceso declarativo común ordinario de Castilla o «solemne orden de los juicios en todos sus tiempos» (situación que poco variaba en lo que a dilación se refiere en la Corona de Aragón) la alegación y prueba del Derecho extranjero (salvo el Canónico y Romano que no se consideran extranjeros en su régimen jurídico, ni la particular 
doctrina auténtica de dichos juristas que no necesitaba de prueba alguna) se considerara un despropósito y se prohibiera siguiendo la tradición histórica surgida en el Fuero Juzgo. Pero tampoco debe olvidarse que en la Pragmática de 1427 de Juan II, se deja claro que no prohíbe el estudio del derecho extranjero (lo que incluso a efectos doctrinales es considerado conveniente) si no sólo su alegación en los escritos de demanda y contestación a ella, o en los ulteriores, para ulterior aplicación.

\section{LA EDAD MODERNA}

La Edad Moderna no supuso grandes cambios en esta materia, sin perjuicio de los Decretos de Nueva Planta que unificaron el Derecho privado nacional pues en Valencia se suprimió su Derecho valenciano por apoyar al pretendiente Carlos en la Corona y que salió derrotado frente a Felipe V.

El reinado de Carlos III (antecedente próximo a la edad contemporánea) supone un cambio en la concepción jurídica del extranjero y sus derechos, sobre todo en materia comercial e industrial como señala Tomás Ortiz de la Torre, J.A. en su monografía «el régimen jurídico de la extranjería en la España del S. XVIII y la participación del extranjero en la industria nacional».

En este sentido dicho autor, se refiriere al reinado de Carlos III y al aumento de asuntos - con elementos de extranjería- reclamados en los Tribunales del Reino (- por la llegada de muchos extranjeros a España, aprovechándose de lo dispuesto en la Reales Cédulas y las Reales Provisiones para la repoblación de los distintos espacios geográficos en nuestro territorio; y por el aumento de las relaciones comerciales con los países del entorno o de estos en nuestras colonias-).

De la misma forma, Jesús Acedo Rico (Conde de la Cañada), quizá el mejor procesalista del S. XVIII (del que debe destacarse el amplio y destacado estudio de su persona y obra por el profesor Cachón Cadenas con el título «Notas sobre la vida y la obra de Juan Acedo Rico, primer Conde de la Cañada», publicado en la obra Derecho, Justicia, Universidad. Liber Amicorum de Andrés de la Oliva Santos, coordinado por Ignacio Díez Picazo Giménez y Jaime Vegas Torres. Ramón Areces. Madrid. 2016. Tomo I. Pág. 493-529) se planteó por primera vez la cuestión que abordamos.

Acedo Rico era miembro del Consejo Real de Castilla a donde llegaban en última instancia los recursos extraordinarios contra las

(C) UNED. Revista de Derecho UNED, núm. 22, 2018 
sentencias y resoluciones judiciales (o administrativas, sobre todo las referidas al derecho local) firmes o no - según el caso- (de todo tipo, por tanto civiles, penales, administrativas de ámbito local o referidas al Reino y en especial las referidas a los conflictos entre la jurisdicción ordinaria y las especiales para determinar el órgano competente como era el caso de los recursos de fuerza y protección...) de Corregidores, Jueces y sobre todo Audiencias.

Es en su obra «Apuntamientos prácticos para todos los trámites de los juicios civiles» publicada en Madrid en 1793 (hay edición posterior de 1794 y otra de mediados del S. XIX con distinto título) donde se muestra partidario - y es la primera vez que lo hace un jurista nacional- de que los jueces nacionales de la jurisdicción ordinaria civil (puesto que en la jurisdicción especial mercantil de los Cónsules no se daba esta problema) mantuvieran un "fuero amplio y exclusivo» de atribución de su jurisdicción lo que es llamado por algún procesalista como de competencia judicial nacional (y que los internacionalistas, sin embargo denominan competencia judicial internacional y que se atribuye o distribuye mediante «fueros» como los del art. 22-1 LOPJ) en asuntos con elementos de extranjería.

Consiste en la defensa de la exclusividad de la jurisdicción ordinaria nacional para todos estos casos (según otros «fuero exclusivo de la competencia nacional») según el cual se declararían siempre competentes los juzgados y tribunales para evitar así toda indefensión al extranjero (en caso de que se declararan incompetentes de no concurrir los denominados hoy «fueros comunes» de atribución del objeto procesal deducido a la jurisdicción nacional y concurrir un elemento de extranjería en el proceso civil seguido en España, previstos en el art. 22-1 LOPJ).

Y planteó en esta obra (influenciado por el pensamiento ilustrado y enciclopédico francés de la época, por las nuevas corrientes económicas de base liberal que venían de América frente al proteccionismo económico entonces vigente, y sobre todo fundándose en la doctrina medieval estatutaria ya examinada) si deben aplicar nuestros jueces a los extranjeros la ley nacional del foro, o por el contrario deben aplicar la suya propia dándose entrada, en este caso, a la aplicación de la norma extranjera referida a su estatuto personal. (Antecedente por tanto en más de medio siglo de la aplicación y prueba del derecho extranjero en el proceso seguido en España en el orden jurisdiccional civil).

También plantea en la obra citada, si deben en España - o noreconocerse las sentencias dictadas en países extranjeros (por ello, 
extranjeras) cuando deban producir efectos en España. (Antecedente, por tanto, del juicio de reconocimiento de sentencias extranjeras que por primera vez formó parte de la LEC 1855 y que Pedro Gómez de la Serna justificó en su obra «Motivos de las variaciones que ha introducido la....» publicada en Madrid en 1857 y que antes venía haciendo la jurisdicción consular respecto a sentencias extranjeras referidas a ciertos contratos mercantiles).

Debe destacarse también que Felipe V estableció por Real Decreto de 7 de Julio de 1727 una jurisdicción especial de carácter personal para los extranjeros denominada «jurisdicción del fuero de extranjería» que encomendó a la decisión de los Jueces Conservadores de extranjeros y en la que aplicaban el derecho nacional (por tanto, en clave de extranjería y no conflictual) para proteger los derechos de ellos bajo una visión, claramente, paternalista. Fernando VI la modificó por Real Orden atribuyendo esa jurisdicción a los Gobernadores militares en causas seguidas contra extranjeros o entre extranjeros entre sí dentro del ámbito que especifica. Y la Real Orden de 14 de Diciembre de 1788, la concretó.

Estas tres normas, son los antecedentes del Decreto de extranjería de 17-11-1852 que reguló derechos de carácter público y privado de los extranjeros equiparándolos a los de los nacionales (los derechos públicos eran más limitados) y a los que se aplica el derecho del foro (en clave de extranjería y no en clave conflictual -en este momento, por tanto desde 1852 a $1864-$ y no como propugnaba la doctrina estatutaria) y donde inicialmente se partía de un régimen de reciprocidad para el reconocimiento de sus derechos, por tanto dependiendo dicho régimen del tratamiento que daba el país extranjero - en cuestión y de forma concreta- a nuestros nacionales residentes en él.

Se aplica a los derechos de los extranjeros la norma material nacional o del foro y es competente la jurisdicción especial de extranjería allí donde reside, jurisdicción que estuvo vigente desde tal fecha, así la inicial de 1727 -inclusive al RD de 1852 - y lo fue en clave de extranjería hasta 1864, aproximadamente. El Decreto de Unificación de Fueros de 6 de Diciembre de 1868, suprimió esta jurisdicción especial. (Aunque en ciertos ámbitos y ciertos recursos conocía la jurisdicción ordinaria civil desde 1855 hasta el Decreto de Unificación de fueros conforme a la doctrina legal del TS sentada en los recursos de casación por infracción de ley (prueba y aplicación del derecho extranjero) o para el reconocimiento y ejecución de sentencias extranjeras, según lo dispuesto en la LEC 1855. 
Con la supresión de esta jurisdicción privilegiada en 1868 pasarán sus competencias a la Jurisdicción ordinaria, sea cual sea el orden competente, que en la mayor parte de los casos es el orden civil. Sin embargo, en lo material o sustantivo este Decreto siguió estando vigente en el S. Xx, aunque debe ser puesto en armonía desde 1889 que entró en vigor el Código Civil, con el art. 27 CC de éste -en su redacción originaria-que reguló los derechos de los extranjeros y que desde esta fecha 1889 se desliga del principio de reciprocidad del Decreto de extranjería de 1852, como ya antes había comenzado a declarar la jurisprudencia del TS, anteriormente, sentando esa doctrina legal desde 1864 y aplicándose a cualquier extranjero al margen de la reciprocidad que tuviera el estado de origen con España.

Cierra esta Edad Moderna - por las razones expuestas en el siguiente epígrafe se incluye en la Moderna y no en la Contemporánea- y como último homenaje al sistema legal de recopilación frente al de codificación (iniciado y desarrollado en varios países de nuestra órbita desde fines del S. XVIII, como Francia) la Novísima Recopilación publicada en 1805. Su autor es Juan de la Reguera Valdelomar. Consta de cinco tomos y doce libros y un tomo más (-el sexto- de apéndices referido a disposiciones no incluidas en el texto de 1805 e índice de la obra) publicado en 1807. Fueron publicados por la Imprenta Real y en nada modifica la etapa precedente desde las Partidas en lo que al objeto de este trabajo se refiere, es decir, la aplicación exclusiva en el proceso civil español de las normas nacionales al caso concreto, en clave de extranjería.

\section{LOS INICIOS DE LA EDAD CONTEMPORANEA EN ESPAÑA}

El siglo XIX, con el inicio de Guerra de la Independencia Española, supone el nacimiento de nuestra Edad Contemporánea española (aunque en Europa se considera determinante el año 1789 que es el del comienzo de la Revolución Francesa, y en los EEUU de América el año 1776 que es el de la proclamación de su independencia). Es la razón por la que la Novísima Recopilación se incluye en el anterior periodo. Y es relevante en la materia desde varias perspectivas:

La CONSTITUCIÓN DE CÁDIZ de 1812 es el texto jurídico más significativo de su inicio. La misma, dentro del Poder Judicial, se refiere a la instauración de un Tribunal Superior de Justicia que se establece por el Decreto de 17 de Abril de 1812 y que se constituye ese 
mismo año, el 15 de Diciembre, con la designación o nombramiento de sus componentes por las Cortes denominados «Ministros del Tribunal Superior».

No llegó a dictar sentencias sobre sus competencias específicas, es decir, pronunciarse sobre el recurso de nulidad (existían antecedentes en casos tasados y equivalía al extraordinario de casación por quebrantamiento de las formas esenciales del juicio de las LEC de 1855 y 1881 hoy denominado extraordinario de infracción procesal, aunque con notorias diferencias); el de segunda suplicación (del que existían antecedentes y que era un recurso especial intermedio entre la apelación y la casación por infracción de ley, en cuanto última instancia ante las Chancillerías o Audiencias para en el que no bastaba la simple infracción de ley) y el extraordinario de injusticia notoria (del que existían antecedentes de los que conocían Audiencias y Chancillerías, equivalente a la casación por infracción de ley y revisión, pero con notables diferencias) por lo tanto de su exclusiva competencia y en última instancia.

La Ley de 9 de Octubre de 1812, regulaba este recurso especial de nulidad que era restrictivo en su ámbito de aplicación, así como el Decreto de 13 de marzo de 1814 que establecía el Reglamento del Tribunal Superior de Justicia. Poco después en 1814, tras la llegada de Fernando VII a España de su destierro en Francia, son derogadas la Constitución de Cádiz de 1812 como dicha Ley y Decreto reguladoras del régimen jurídico de este Tribunal.

\section{LA RESTAURACIÓN FERNANDINA. VUELTA AL MODELO CONSTITUCIONAL}

Suprimida la Constitución de 1812 y la legislación concordante se vuelve al sistema anterior a dicha Constitución, es decir, al modelo existente en tiempos de Carlos IV (Leyes de Recopilación) que era el modelo de los Austrias y el borbónico instaurado por Felipe V con las especialidades dichas sobre la jurisdicción especial de extranjería.

Habrá que esperar a la Constitución de 17 de julio 1837 que reinstaura aquel Tribunal (y que confirmaron las Constituciones posteriores) y que pasará a denominarse Supremo. Establecido el Tribunal Supremo y su régimen jurídico en virtud de una Ley y su Reglamento que son de 1838, este mismo año se le atribuye el exclusivo conocimiento de los recursos de nulidad mencionados en el epígrafe anterior de conformidad con la Ley de 21-7-1838 y el Decreto de 4 de Noviembre de 1838 que regulan los mismos. 
Los recursos de nulidad son el antecedente directo de los recursos de casación por quebrantamiento de forma, pues en España, a diferencia con Francia, primero se introdujo la casación por quebrantamiento de forma a través de estos recursos de nulidad y con posterioridad el recurso de casación por infracción de ley en 1852 en el ámbito de la jurisdicción de Hacienda. Ambas modalidades del recurso de casación en atención a sus motivos - quebrantamiento de las formas esenciales del juicio o infracción de ley o de la doctrina legal del TS al interpretarla al caso concreto- pasaron a la LEC de 1855. Antes se había dictado el 26-9-1835 el Reglamento para la Administración de Justicia que no ofrece particularidades importantes en lo que concierne a nuestro trabajo.

X. PRECEDENTES DE LA REFORMA. EL PROYECTO DE GARCÍA GOYENA DE CÓDIGO CIVIL DE 1851. EL DECRETO DE EXTRANJERÍA DE 17-11-1852. EL ESTABLECIMIENTO EN ESPAÑA EN 1852 DEL RECURSO DE CASACIÓN POR INFRACCIÓN DE LEY Y DOCTRINA LEGAL COMPETENCIA EXCLUSIVA DEL TS. LA INSTRUCCIÓN DEL PROCEDIMIENTO CIVIL DE 1853

PROYECTO DE CÓDIGO CIVIL 1851. Hay que destacar que, de 1851 es el Proyecto de Código Civil de García Goyena y que como tal proyecto no llegó a estar vigente como Ley. Pese a ello resulta necesario hacer referencias al mismo pues incide sobremanera sobre el estado de la cuestión objeto de estudio.

Este proyecto tuvo consecuencias muy importantes para nuestro país entre las que deben destacarse:

a) Supuso que, en España - a diferencia con la mayor parte de los países europeos inmersos en el denominado sistema jurídico continental también denominado sistema de derecho común (a diferencia de otros sistemas jurídicos como el del common law y demás sistemas que nos resultan lejanos y que no optaron en ese momento por la codificación)_- primero se produjo la codificación procesal civil en 1855 y 1881 y después la civil en 1888-89. Es decir, primero la codificación procesal y después la codificación material civil. Lo cual tuvo importantes consecuencias pues el TS a través de su doctrina legal al pronunciarse sobre los recursos de casación por infracción legal tuvo que colmar muchas lagunas del «nuevo sistema» que sucedió a la Novísima Recopilación y que no estuvo codificado en cuerpo legal hasta 1888-89. 
Pero esta afirmación es sólo en parte cierta; lo es para el derecho sustantivo civil, mas no para el derecho sustantivo mercantil pues primero se produjo la codificación material plasmada en el C de C de 1829 y al poco llegó la procesal mercantil en la Ley de Enjuiciamiento de Negocios de Comercio de 1830. La jurisdicción consular mercantil seguirá vigente hasta el Decreto de Unificación de Fueros de 1868 en que desaparece y pasa a formar parte, su objeto, de la ordinaria civil como así lo confirmó la Ley provisional del Poder Judicial de 1870. Y desde 1868 hasta 1881 sólo estuvo parcialmente en vigor la LENC de 1830. La LEC de 1881 la derogó al unificar el sistema procesal civil y mercantil dentro de ésta pese a su denominación única de (enjuiciamiento) civil.

b) Este proyecto influyó notablemente en el ulterior CC de 188889. Muchos de sus artículos son semejantes a los del ulterior en términos comparativos.

c) Al no ver la luz muchas de las instituciones en él reguladas, por no llegar a convertirse en ley vigente si no sólo en un proyecto, siguieron siendo lagunas legales que tuvieron que ser completadas por la jurisprudencia del Tribunal Supremo (en nuestro caso desde 1864 en los asuntos civiles; y desde 1868 en los mercantiles). Fue posible al establecerse el recurso de casación por infracción de ley y doctrina legal en la LEC de 1855. Esto influirá decisivamente en nuestra institución sobre la opción a seguir en particular desde este momento, por las razones que seguidamente veremos.

El TS tuvo que optar entre el sistema histórico de la aplicación del derecho nacional exclusivamente en el proceso civil en España tramitado, o por el contrario si daba entrada a la aplicación del derecho extranjero una vez probado. Exclusividad del derecho nacional aplicado en el proceso civil aquí tramitado, versus aplicación del derecho nacional o del extranjero según la disponibilidad en uno u otro sentido de la «norma» de conflicto que no es legal si no jurisprudencial según la doctrina estatutaria.

d) El proyecto de CC de García Goyena de 1851 pese a ser muy escueto, al regular la aplicación de las leyes nacionales en sus primeros artículos (art. 1 y ss. dentro del primer libro y título) da entrada por primera vez a que se pueda aplicar el derecho extranjero conforme a la vieja teoría estatutaria de Accursio, sobre todo pensada para el ámbito del estatuto personal o de las personas. A los españoles vivan en España o en el extranjero se les aplicará la ley nacional española de su estatuto personal. A sensu contrario sin decirse expresa- 
mente para los extranjeros la de su nacionalidad. Se establece el estatuto real, y el contractual y el de sus formas para aplicar la norma nacional o extranjera.

Deja abierta la vía a que a los extranjeros residentes en España se apliquen las leyes extranjeras reguladoras de dicho estatuto personal, es decir que por el hecho de pasar nuestra frontera y establecerse en España siguen manteniendo su estatuto personal regulado por su ley extranjera. Pero se determinan en el Proyecto las exclusiones del actual art. $8 \mathrm{CC}$ (muy semejantes a las de su redacción originaria de 1888-89) para las leyes penales, de policía y seguridad pública y las procesales (dígase derecho penal, público-administrativo y procesal).

e) No se preveía en el Proyecto de CC de 1851 la necesidad de probar el derecho extranjero antes de su aplicación. Como veremos seguidamente la jurisprudencia del TS colmó la laguna de la inexistencia de la norma de conflicto que hace posible aplicar la ley extranjera según el estatuto personal o contractual; así como todos los requisitos necesarios para la prueba del derecho extranjero.

f) El proyecto de CC de 1851 supuso una vía sin retorno (pese al ulterior Decreto de extranjería de 1852) para la aplicación del derecho extranjero en clave conflictual y no de extranjería. Es decir, una vía sin retorno para que en breve la aplicación exclusiva del derecho nacional llegara a su término respecto al proceso civil seguido en España con elemento extranjero y dando entrada a la aplicación, previa prueba, de las normas extranjeras privadas (civiles y mercantiles).

DECRETO DE EXTRANJERÍA 1852. Reguló los derechos de los extranjeros, pero lo hizo en clave de extranjería (se sigue con la aplicación exclusiva a los extranjeros, de las normas nacionales); y no en clave conflictual lo que supone en cierto sentido aparcar y romper las expectativas del proyecto de CC de 1851 de García Goyena antes examinado y la reafirmación y el mantenimiento del ideario histórico sobre esta cuestión que podría considerarse ultramontano.

Aunque en términos garantistas de tutela judicial, podría ser alabado, en el sentido de reafirmar la exclusividad de nuestra jurisdicción (formaba parte del ideal de nuestra historia patria) para casi todos los casos (cualquiera que fuera el fuero que determinase nuestra competencia jurisdiccional incluso violando competencias exclusivas de otro estado o al amparo de todo fuero que pudiera ser tachado de exorbitante). Actuaba esta jurisdicción de forma muy "paternalista» y 
lo era en cierta medida «privilegiada» — como toda jurisdicción especial- respecto a los extranjeros si acudimos al derecho comparado vigente en este momento (mediados S. XIX) en otros países de nuestra área de influencia.

El Real Decreto de extranjería de 1852 reestructura la jurisdicción especial de extranjería y equipara los derechos de extranjeros y españoles bajo el principio de reciprocidad y aplica a los derechos de los extranjeros nuestra ley nacional material vigente en clave de extranjería y no conflictual como señalé (es decir, no se establecen normas de conflicto para aplicar el derecho privado extranjero al aplicar exclusivamente el nacional.

Entiéndase en términos de "comprensión» respecto a derechos subjetivos públicos y privados que pudieran corresponder a los extranjeros, especialmente derechos públicos, (recalco de nuevo ciertos derechos públicos - y no los privados- extendidos más allá de la ciudadanía) y que quedaban dentro de los referidos en el Proyecto de García Goyena art. 7 y del vigente art $8 \mathrm{CC}$ - muy semejante a la redacción originaria de 1888-1889-, (es decir materias de derecho público en que se aplica exclusivamente el derecho nacional tanto a nacionales como extranjeros) a través de esta jurisdicción especial de extranjería en los lugares donde residiesen estos Juzgados o Tribunales de extranjería. Remito en sus antecedentes a lo expuesto en la Edad Moderna.

EL DECRETO REGULADOR DE LOS DELITOS DE CONTRABANDO Y DEFRAUDACIÓN PARA LA JURISDICCIÓN ESPECIAL DE HACIENDA. También es de 1852. Regula el procedimiento hasta la sentencia y por primera vez establece para esta jurisdicción especial el recurso de casación por infracción de ley del que conocerá exclusivamente el Tribunal Supremo y su Sala correspondiente (dígase sección especial, en ese momento, para conocer de este especial recurso de casación).

Este recurso poco después se introduce con carácter general en la LEC de 1855, donde por primera vez se reguló en el ámbito civil el recurso de casación por infracción de ley. Y reguló también el recurso de casación por quebrantamiento de las formas esenciales del juicio adecuándolo al precedente recurso de nulidad establecido por la Ley de 1838. Atribuyendo ambos recursos exclusivamente a la Sala de lo civil del TS.

Poco después la jurisdicción especial de Hacienda fue suprimida, tema en el que no entro por no guardar relación con este trabajo. 
INSTRUCCIÓN DEL PROCEDIMIENTO CIVIL ORDINARIO. De 30 de Septiembre de 1853, es la Instrucción del procedimiento civil ordinario del Marqués de Gerona (José de Castro y Orozco, es su nombre y es el entonces Ministro de Justicia) aplicable al procedimiento civil ante la jurisdicción ordinaria - por tanto a nacionales o extranjeros donde no existían juzgados o tribunales de la jurisdicción especial antes dicha-. También se aplicó esta Instrucción en la especial de Hacienda, aunque este mismo año 1853 fue suspendida su aplicación en el procedimiento de Hacienda por Orden Ministerial de su Ministro de Hacienda de 22-10-1853.

El 17 de Enero de 1854, fue suspendida su aplicación al procedimiento ordinario civil por el nuevo Ministro de Justicia que sustituyó a Castro y Orozco lo que supuso (por el vacío legal originado) la aceleración de los trabajos de la Comisión de Codificación en la Sección dedicada al proceso civil y que viera la luz la primera Ley de Enjuiciamiento Civil, que es de 5 de Octubre de 1855 y que reguló por primera vez en lo que afecta a este trabajo los requisitos del reconocimiento o exequatur de sentencias extranjeras (algunos son comunes a la aplicación y prueba del derecho extranjero en el proceso civil, que se sigue en España).

\section{LA LEY DE ENJUICIAMIENTO CIVIL DE 1855}

La LEC de 1855 supuso dos novedades importantes dignas de examen en lo que afecta a este trabajo.

En primer lugar, introdujo el genuino recurso de casación por infracción de ley y doctrina legal por primera vez en el proceso civil (antes se introdujo en 1852, como señalé, en la jurisdicción especial de hacienda en su proceso especial) y el recurso de casación por quebrantamiento (infracción) de las formas esenciales del juicio procedente del anterior recurso de nulidad de 1838. Pues bien, el recurso de casación por infracción de ley o de la doctrina legal del TS permitió a través de su jurisprudencia cubrir la laguna legal de los requisitos de la previa prueba del derecho extranjero para su posterior aplicación en la sentencia como veremos en el siguiente punto.

En segundo lugar, la LEC de 1855 permitió por primera vez el reconocimiento y ejecución en España de las sentencias civiles dictadas en el extranjero (de sentencias extranjeras, en términos generales, se habla en la LEC) a las que por tanto se aplicaba el derecho extranjero (si eran civiles o incluso mercantiles, aunque es discutible pues nada 
se establecía para la jurisdicción consular). Era la otra cara de la moneda a la prueba del derecho extranjero para su aplicación en el proceso civil seguido en España.

Carecería de sentido que en España desde 1855 se pueden reconocer sentencias extranjeras dictadas en otro país que aplica sus normas (las suyas propias o de otro país) cuando deben producir efectos en España y que por el contrario no se puedan aplicar esas mismas normas extranjeras en el proceso civil que se sigue en España ante nuestros tribunales de concurrir un elemento de extranjería (estatuto personal, real, obligacional o de las formas) sino exclusivamente las nacionales. De ser así ningún extranjero solicitaría su aplicación (al ser las del foro las aplicadas) ante nuestros tribunales y se verían forzados a solicitarlo ante sus tribunales de origen para que luego fueran reconocidas en España.

Además, el control de sus presupuestos (orden público y fraude de ley) siempre será menor en caso de exequatur (aunque esto soy consciente que es muy discutible, pese a la sumariedad del juicio de reconocimiento, que en el proceso civil seguido en España (en la mayor parte de los casos plenario) lo que sería un contrasentido, y además podría originar algún incidente diplomático la denegación sistemática del exequatur, que nunca se producirían en el plenario seguido en España. Por ello el TS desde 1864 se vio obligado a permitir la aplicación de las normas extranjeras privadas (fuera del ámbito público del art. $8 \mathrm{CC}$ ) siempre que se prueben previamente y estableciendo los requisitos para su aplicación entre los que estaba el orden público y el control del posible fraude de ley.

Es decir, en España debía probarse el derecho extranjero para que se pudiera aplicar éste, en la sentencia dictada en nuestro país. Aunque los requisitos exigidos tanto para su prueba como para su aplicación constituían una laguna legal que colmó el TS (véase el siguiente punto) aunque tuvo en cuenta algunos de los establecidos para el «exequatur». Pero la LEC de 1855 (y después con más detalle la LEC de 1881) reguló expresamente la otra cara de la moneda, es decir, que el derecho extranjero determinado al caso concreto en la sentencia extranjera podía ser reconocido en España para poder ser aplicado o ejecutado materialmente aquí, conforme a ese derecho extranjero y a través del reconocimiento de dicha sentencia extranjera.

Y se reguló en la primera parte de la LEC — dedicada a la jurisdicción contenciosa-, en el Título XVIII denominado «de la ejecución de las sentencias», dentro de la sección segunda bajo el título «de las 
sentencias dictadas por los Tribunales y Jueces extranjeros, en los art. 922 a 929. (La sección primera se refería a la ejecución de las sentencias nacionales).

A través de un proceso declarativo, especial y complejo denominado reconocimiento de sentencias extranjeras y de una ulterior ejecución material tras éste, si la sentencia reconocida era de condena, pero siguiendo el trámite procesal del proceso civil español de ejecución. Por eso se denominó también proceso de exequatur, aunque propiamente el exequatur sólo procedía en cuanto se precisara una ejecución ulterior tras su reconocimiento y según las normas comunes de la ejecución previstas en la LEC de 1855 cuando la pretensión era de condena.

Si sólo se necesitaba de una mínima actividad complementaria para su inscripción en un registro público bastaba que así lo dispusiera expresamente el juez en el Auto (que equivalía a una sentencia al poner fin a la cuestión) cuando la pretensión y la sentencia que la reconocía era constitutiva, sin perjuicio de que sus efectos se produjeran desde el hecho que la originase, desde la interposición de la demanda, o desde la sentencia firme (por tanto efectos ex nunc o ex tunc de la sentencia y por tanto de la cosa juzgada). En las pretensiones de mera declaración, estimadas en la sentencia, bastaba con su mero reconocimiento siendo innecesaria ejecución alguna.

Así pues, si las sentencias dictadas en otro país según el derecho extranjero podían ser reconocidas en España para su ulterior ejecución o la simple aplicación de tal derecho según la pretensión homologada, parecía lógico que en el proceso civil seguido en España - y con más garantías procesales- se debía permitir la prueba de ese derecho extranjero, para su ulterior aplicación en la sentencia nacional dictada en España. (Ver siguiente número). Esta era igualmente la legislación y/o la práctica seguida en el extranjero desde ambas perspectivas, es decir las dos caras de la misma moneda en cuanto llevaban al mismo resultado.

\section{JURISPRUDENCIA DE LA SALA CIVIL DEL TS EN RECURSOS DE CASACIÓN POR INFRACCIÓN DE LEY O SU DOCTRINA LEGAL AL AMPARO DE LAS LEC DE 1855 Y 1881}

Será la Jurisprudencia del TS a través de su Sala de lo Civil la que fue estableciendo su doctrina legal al pronunciarse sobre los recursos de casación por infracción de ley o infracción de su doctrina legal (es 
como la casación por infracción legal en cuanto al trámite procedimental externo, aunque se aduzca como motivo independiente). Estableció los requisitos exigibles a la prueba previa del derecho extranjero, así como los exigibles para su aplicación una vez probado. O de la propia LEC para reconocer por Auto las sentencias extranjeras en que se declaraba el derecho extranjero aplicado.

Así será el TS mediante su doctrina legal quien establecerá los requisitos exigibles para la prueba del derecho extranjero y cuando es procedente su aplicación o ejecución material y siempre en clave conflictual (obsérvese ya no, como en el derecho histórico anterior a la LEC de 1855, en clave de extranjería).

Pero para la procedencia de su aplicación o no al caso concreto, se configuró también una doctrina legal sobre el recurso de casación por infracción de ley surgida sobre todo del reconocimiento de las sentencias extranjeras en España. (Así la noción de orden público y fraude de ley será extensible no sólo al juicio de reconocimiento de sentencias extranjeras en España - v.gr. francesas- sino también a la aplicación del derecho extranjero - francés- en España en el proceso civil español, una vez probado).

Esos requisitos jurisprudenciales exigidos a la prueba del derecho extranjero son que se pruebe el contenido, alcance, y vigencia del derecho extranjero, como si de un hecho se tratara. Por tanto, si sólo basta probar el o los preceptos del derecho extranjero (contenido) y su vigencia y por qué medios de prueba; o se exige además probar en el caso concreto que se sigue ante los jueces y tribunales españoles la interpretación jurisprudencial (alcance) que del mismo hacen los tribunales del país en cuestión al aplicar dicho derecho en casos iguales.

Esta doctrina legal del TS determina cuáles son los medios de prueba exigidos para probar el derecho extranjero y destaca como jurisprudencia en múltiples sentencias que basta el dictamen escrito y en su caso traducido (salvo que la norma sea de Iberoamérica redactada originariamente al castellano) de dos jurisconsultos del país cuyo derecho extranjero ha de probarse. Aunque, establece además que son válidos los otros medios de prueba de que decidan valerse las partes para la práctica de la prueba siempre que conduzcan a un resultado positivo.

Sí deja claro el TS como doctrina legal que el dictamen de los juristas extranjeros plasmado en el documento aportado con la demanda, su contestación o después no tiene carácter de prueba legal para los jueces nacionales (idem art 33 de la vigente LCJIC — L. 29/2015 de 
30 de julio- que confirma expresamente esa doctrina legal del TS), al tratarse de una prueba pericial sometida, por ello, a la libre apreciación de los jueces y tribunales siempre que se ajuste a las reglas de la sana crítica o máximas de la experiencia según la LEC del momento. Así no vincula a los jueces tener como válido ese dictamen plasmado en un documento - del que resulta la prueba del derecho extranjeroaunque deberá motivarse y fundamentarse en la sentencia a efectos de la prueba pericial y según las reglas de la sana crítica porque el juez estima como existente y vigente ese derecho, o se aparta a efectos de prueba de lo en él dispuesto.

Tampoco vincula a los jueces, que una vez probado tal derecho extranjero por este dictamen, tenga que formar parte como contenido material de la sentencia dictada por nuestros jueces y tribunales, a efectos de su ulterior aplicación (concretamos que me refiero a su aplicación, tras la prueba). Se añade a esta doctrina legal —establecida por la reiterada jurisprudencia del TS - que este dictamen no afecta al conocimiento que los jueces nacionales tengan del derecho extranjero cuya prueba sirve para completar el conocimiento (privado) que éstos tengan del mismo y está sujeta, por ello, a la libre apreciación de la prueba, resaltando que la prueba del derecho extranjero en todo caso es una cuestión de hecho. (Obsérvese que esta doctrina se confirma 150 años después por el art. 33 LCJIC ya señalado).

Aunque esta cuestión de hecho, en cuanto prueba — que ademáses del derecho, exige respetar las garantías fundamentales del proceso, que si son vulneradas deben denunciarse en apelación y casación (en este caso por quebrantamiento de las formas esenciales y las garantías fundamentales del derecho a la prueba. Y curiosamente en esta cuestión apenas encontramos jurisprudencia del TS del S. XIX y $\mathrm{xx}$, repito de nuevo, respecto a la casación por quebrantamiento de las formas esenciales o de las garantías procesales fundamentales de la prueba del derecho.

Confirma esta doctrina legal, respecto a la cuestión material de la aplicación del derecho (no a la formal, de su prueba) que de esta forma se evita juzgar a los extranjeros por una única ley en lo sustantivo o material (la del foro, o en clave de extranjería como en nuestro derecho histórico) dando entrada a la aplicación de la ley extranjera que corresponda a su estatuto personal, real, contractual o el formal en clave conflictual, como se hacía en muchos Estados Europeos desde comienzos del S. XIX. Aunque todavía no existe una regulación legal de las normas de conflicto (pero sí - desde entonces- una regulación de creación jurisprudencial del TS a través de este medio indirecto que es la doctrina legal para colmar lagunas 
legales). La primera vez que se establece la regulación legal mediante normas de conflicto es en el Código Civil redacción originaria en 1888-89 en los artículos 9 a 11.

Las leyes procesales nacionales (o del foro término usado en derecho internacional privado) se aplican por igual siempre a nacionales y extranjeros como en la actualidad (a salvo los art. 3 y 4 LEC) y en nuestro derecho histórico precedente. (Art. 8 CC redacción anterior y art. 1, 3 y 4 LEC, aunque alguna salvedad).

Aunque existían duplicidades normativas que a la vez eran divergentes, cuando la misma cuestión se regulaba en normas materiales y procesales y debía regirse por ambas a la vez. Así la doctrina legal del TS estableció, respecto a la capacidad de la mujer casada extranjera, que en lo sustantivo se rige (rija) por «su» ley material extranjera que es la correspondiente a su estatuto personal; pero para comparecer en el juicio seguido en España con elemento extranjero y completar su capacidad procesal tenía que hacerlo conforme a lo establecido en las LEC de 1855 y 1881 que remitían a la ley material española (Partidas y Leyes de Recopilación y después CC de 1889) a los meros efectos procesales; siempre conforme a esa doctrina legal del TS establecida en los recursos de casación por infracción de ley del S. XIX.

Y esta jurisprudencia la establece el TS al pronunciarse sobre los recursos de casación por infracción de ley y parece que la primera sentencia es de 21 de junio 1864 (según Miralles Sangro, P.P en su obra Aplicación del derecho extranjero en el proceso y tutela judicial, Madrid. 2007) que examiné en el repertorio de Jurisprudencia civil del TS correspondiente a esa fecha; y las sentencias posteriores van perfilando esta doctrina legal. No encontré, como señalé, jurisprudencia del S. XIX del TS referida al recurso de casación por quebrantamiento de forma anterior a esta fecha, ni de su antecedente el recurso de nulidad (lógico, en este caso al aplicarse de 1838 a 1855 la lex fori y no la extranjera, al estar excluida de toda alegación, fundamentación y prueba).

Entiendo que para este momento - tercer tercio del S. XIX- dicha jurisprudencia fue de lo más progresista, pues por primera vez se admite por el TS, confirmando la jurisprudencia menor de sus órganos inferiores, que el derecho extranjero es susceptible de aplicación en España por los tribunales del orden civil si es alegado y sobre todo probado; frente a la situación anterior impuesta por la tradición de nuestro derecho histórico que prohibía su alegación y prueba dado que sólo se podía aplicar el derecho nacional. Pasa a aplicarse por tanto el derecho material extranjero en clave conflictual y no de ex- 
tranjería cuando se trata del derecho privado civil (o el mercantil desde 1869).

También fue muy progresista porque en este momento no existía todavía un código material vigente (CC) que estableciera las normas de conflicto. Es decir en qué supuestos procedía la aplicación de derecho material extranjero y cuando no; se respetó por influencia del derecho comparado esa clave conflictual en el ámbito del estatuto personal o real del extranjero o el de las obligaciones y las formas del contrato si éste se celebraba en el extranjero conforme a la ley de ese país.

Obsérvese que entonces todavía no existía un Código civil vigente pues, en nuestro país, se promulgó primero el Código de Comercio de 1829 y su Ley de Enjuiciamiento Mercantil en 1830; sigue la Ley de Enjuiciamiento Civil en 1855 y después la LOPJ de 1870 a la que siguió la LEC 1881. Normas anteriores al Código Civil que vió la luz en 1888-89. A diferencia con otros países de nuestro entorno, como señalé, que siguieron el orden inverso en que primero se procedió a la codificación material civil plasmada en su texto y después se procedió de igual forma a la codificación procesal civil.

No se olvide que en España se intentó seguir este orden, pero el Proyecto de Código Civil de 1851 de García Goyena (concordado y comentado en 4 volúmenes, publicados en Madrid en 1852) no salió adelante, sin perjuicio de la influencia que pudo tener en él el derecho comparado; y como influyó en esta doctrina legal del TS. No se olvide además que las leyes procesales de 1830, 1855, 1870 y 1881 no regularon la prueba del derecho extranjero, hasta que se hace en la LEC 2000 y antes se hace en el CC en su art. 12-6-2 tras la reforma que se introdujo en su Título Preliminar en 1974.

\section{EL DECRETO DE UNIFICACIÓN DE FUEROS Y LA LEY PROVISIONAL DEL PODER JUDICIAL DE 1870. LA LEC DE 1881}

Tampoco se debe desdeñar el Decreto de Unificación de Fueros de 6-12-1868 que trajo consigo la supresión de las jurisdicciones especiales en favor de la jurisdicción ordinaria y en este sentido es verdadero precedente y antecedente de la Ley Provisional Orgánica del Poder Judicial, de 18-9-1870, que pese a ser provisional estuvo vigente con escasas reformas intermedias hasta 1985 y que fue sustituida por la LO. 6/1985 de 1 de Julio del Poder Judicial. 
Esta Ley provisional de 1870 reguló por primera vez (aunque fue objeto de múltiples reformas posteriores en este aspecto) los denominados «fueros de la competencia judicial internacional» o mejor dicho los fueros de atribución de jurisdicción y en su virtud competencia a nuestros tribunales en los juicios civiles ventilados y seguidos en España con elemento extranjero y con gran amplitud para que nuestros Tribunales se declararan competentes en la mayor parte de los casos. Fueros y competencia de nuestros jueces y tribunales en juicios con elemento extranjero aquí sustanciados, detrás de los que estaba la aplicación de la norma extranjera correspondiente a su estatuto personal, o el real, o del lugar y forma de celebración o perfección del contrato, negocio, relación o situación jurídica existente.

El 21 de Junio de 1880, se aprueba la ley de Bases de la posterior Ley de Enjuiciamiento civil que se promulga antes por Real Decreto de 3 de Febrero de 1881.

Siguiendo con la jurisprudencia del TS pese a no existir un Código Civil hasta 1888-89 (el segundo texto es de 24-7-1889) el influjo en esta materia del derecho y la jurisprudencia comparada de los países de nuestro entorno fue grande, y por ello el TS cubrió muchas lagunas que no se planteaban en las antiguas Leyes de Recopilación. En nuestro caso una laguna material derivada de la inexistencia de normas de conflicto hasta el CC de 1889 y la laguna procesal referida a los requisitos de la prueba del derecho extranjero, que hasta 1974 no se reguló conforme al derecho positivo, al serlo por primera vez, en dicha fecha.

Para lo cual el TS tuvo a bien considerar la prueba del derecho extranjero como la de un «simple» hecho (no tenía otra forma, salvo aplicar de oficio un derecho extranjero desconocido y muy difícil de conocer en el S. XIX que estaba fuera del principio o aforismo legal iura novit curia para las normas vigentes españolas debidamente publicadas en la Gaceta o BOE).

«Hecho» que además es derecho objetivo extranjero y que es objeto de prueba a instancia exclusiva de las partes (el actor probaría el derecho objetivo extranjero regulador de su pretensión siempre según la posición que adopte en el proceso al plantear la pretensión, es decir, según reclame la validez o la invalidez de una relación o situación jurídica en la pretensión formulada; y el demandado el derecho extranjero regulador de su excepción material de fondo también dependiendo de la pretensión formulada por el actor) o de las partes en régimen de cierta colaboración con el juez. 
Y esto es así dada la falta de toda regulación de la prueba del derecho en general sea extranjero o nacional - a salvo de la prueba de la costumbre nacional (sin olvidar que la costumbre extranjera forma parte del bloque en conjunto del derecho extranjero). Costumbre que en parte tiene distinto carácter al derecho positivo y que era asimilada también a un hecho en cuanto objeto de prueba así respecto a su reiteración (o prueba de su elemento fáctico) como a sus efectos jurídicos (prueba de su elemento normativo) lo cual parecía lógico en el sentir del momento.

Y ello tuvo su reflejo en los distintos recursos procedentes admisibles sobre la sentencia en que se probó tal derecho extranjero (unos por realizarse la prueba sin las garantías procesales) o se aplicó el derecho extranjero (otros por infringirse la norma extranjera). Así la aplicación del derecho extranjero pasó sobre todo a ser una «quaestio iuris» o cuestión de derecho y es recurrible por la vía del recurso de apelación en caso de violación del derecho material extranjero; y después mediante el recurso de casación por infracción de ley o de doctrina legal (se entiende la extranjera de su TS o T superior). Y no por la casación por quebrantamiento de forma, que sólo podría ser apropiada en caso de que el juez no permitiera probar o desestimara la prueba del derecho extranjero entendido como una cuestión de hecho o «quaestio facti» infringiendo así las garantías procesales del derecho probatorio establecidas en la LEC, que originan esta indefensión.

Y digo la aplicación del derecho extranjero como cuestión de derecho, (no su prueba que sí se consideró un hecho); con la ventaja que el TS de esta forma al ser un recurso de casación por infracción de la ley material (extranjera) podía casar la sentencia de instancia y después dictar otra en su lugar que la reemplazara, resolviendo el fondo. A diferencia con el recurso de casación por quebrantamiento de las formas esenciales del juicio al realizarse la prueba del derecho extranjero (fuera por tanto de la propia sentencia) en que el TS se limitaba a casar la sentencia de instancia y sin entrar en el fondo (al estarle vetado) remitía los autos al Tribunal de origen ordenando al órgano ad quo - repito, sin pronunciarse sobre el fondo- subsanar el vicio en el momento de su comisión y subsanado continuaba el procedimiento de nuevo hasta la sentencia de fondo de la instancia en que se cometió el vicio.

Esto es así; es la historia de nuestro derecho procesal en los juicios ventilados ante nuestros tribunales cuando debía probarse y además aplicarse el derecho extranjero. Y es la jurisprudencia de nuestro Tribunal Supremo en esta materia guste a unos (a mí en particular, me pareció muy acertada para esa época y momento, la segunda mi- 
tad del S. XIX, el sistema seguido por la jurisprudencia del TS ante la falta de regulación legal y que rompe con la anterior tradición histórica de aplicación en todo caso del derecho del foro en clave de extranjería), o disguste a otros.

El Tribunal Supremo en esta jurisprudencia referida a la prueba del derecho extranjero daba por supuesto la necesidad de establecer, como así hizo jurisprudencialmente, «normas» de conflicto que no eran todavía derecho positivo para los supuestos de existir en el proceso civil seguido en España un elemento de extranjería por la influencia del derecho comparado. Es decir, aplicaba al extranjero la norma extranjera correspondiente al estatuto personal de las personas que es la ley de su nacionalidad; o el régimen jurídico de los contratos y sus formas según la ley del lugar donde se celebraron...

\section{EL CÓDIGO CIVIL DE 1888-89 Y EL SISTEMA DE LAS NORMAS DE CONFLICTO}

Las normas de conflicto en principio muy elementales aparecen en el Código Civil redacción originaria de 1888 y posterior de 1889 (el segundo texto de 24-7-1889) en los artículos 9 a 11 pero sin establecer expresamente la obligatoriedad de su aplicación aunque se presume o parece ir implícita en su regulación ¿con la salvedad dicha, de la exclusión previa y voluntaria de la ley, art 6-2 CC? por lo que parece que el Juez debía aplicarlas de oficio.

\section{LA REFORMA DE 1974}

Es el Decreto N. ${ }^{\circ} 1836$, de 31 de Mayo de 1974, el que estableció la redacción del artículo 12 CC y que se acoge en el nuevo Título Preliminar del CC (antes inexistente). A primera vista parece imperativa, de ius cogens, u obligatoria la naturaleza o carácter de la norma de conflicto del art. 12-6-1 CC. Aunque no deja claro si el demandante (o el demandado) expresamente y de forma obligatoria debe invocar la norma de conflicto en su demanda (o en la contestación a ella el demandado), y si además debe hacerlo fundamentando jurídicamente la misma (o en la contestación a ella el demandado), para que se aplique de oficio por el juez el derecho extranjero.

$\mathrm{O}$ si debe hacerlo de oficio el juez, aunque aquellos no lo hagan, $\mathrm{y}$ en este caso no sé cómo puede el juez, conocer de oficio si las partes lo ocultan la concurrencia del elemento de extranjería al no exigirse tampoco en el poder otorgado al procurador la constancia de esta si- 
tuación. Tampoco establece si es aplicable el art. 6-2 CC o está excluido en este caso, es decir si es admisible una previa exclusión voluntaria de la ley aplicable (de la norma de conflicto que remite a la norma extranjera) por vía contractual o negocial anterior al inicio del proceso y que conste en un documento previo a la litispendencia del proceso o por el contrario no es admisible.

Si no fuera obligación del demandante invocar la norma de conflicto ni la norma extranjera aplicable (se limita a fundamentar la demanda con base en la ley del foro nacional) y lo mismo hace el demandado, y el juez no estuviera obligado a su examen de oficio el demandante podría fundar la demanda en el derecho nacional sin alegar ni probar el derecho extranjero y si el demandado no oponía la correspondiente excepción material de fondo de aplicación de otro derecho parece que nuestro juez estaría obligado a aplicar la norma nacional.

A salvo que se acuda a una interpretación forzada y sesgada de su total imperatividad que llevaría a que el juez debe controlar de oficio la aplicación del derecho extranjero y para que ello fuera posible debería configurarse como un presupuesto procesal (pese a su carácter material) y en tal caso parece que en puridad de lógica jurídica le correspondería también de oficio la previa iniciativa probatoria del mismo (que no se impedía en el art. $12 \mathrm{CC}$ ni en la vigente LEC art. 281-2 ni en la LCJIC art 33) o la aplicación de oficio de tal derecho sin previa prueba que no estaba previsto. Y más sin ser parte el Ministerio Fiscal en la mayor parte de los procesos en que se solicita la aplicación del derecho extranjero y que podría encargarse según lo dicho de este fin: control de oficio de la norma de conflicto. Está claro que el MF no está para esto en el proceso civil disponible con elemento extranjero para controlar la norma de conflicto.

No se regulaba hasta 1974 quien debía probar ese derecho extranjero que debe después ser aplicado al caso concreto, fuera de lo consagrado en esta jurisprudencia del TS, que establecía que quién alega el derecho extranjero para beneficiarse del mismo es quien debe probarlo como si de un hecho se tratara.

Por tanto, el actor probará el derecho extranjero que se refiere a los hechos constitutivos de su pretensión según la posición que adopte en un proceso al plantear la pretensión (puede alegar como demandante los hechos constitutivos; o los impeditivos, extintivos o excluyentes, pero en ambos casos constitutivos o constituyentes de su pretensión). Y el demandado el derecho extranjero que se refiere a los hechos que fundan la excepción material por tanto los impeditivos, 
extintivos y excluyentes de la pretensión del actor (salvo que el actor alegue estos y en ese caso serían - como excepción- los constitutivos que justifican la viabilidad de la relación jurídica que impugna el actor) siempre que se trate de un mismo derecho aplicable según la norma de conflicto v.gr el francés, aunque esté regulado en diferentes normas jurídicas.

Que la acción y excepción se contengan en normas extranjeras de ese mismo país aunque estén en diferentes cuerpos legales (así la acción se regula en el CC francés, y la excepción en una ley francesa especial) y donde el demandado además podrá excepcionar que corresponde la aplicación de otro derecho extranjero siempre según nuestra norma de conflicto. Y además ambos demandante y demandado probarán los hechos en que fundan su derecho subjetivo material (acción) o la excepción al mismo, como en todo proceso en que no existiendo elemento de extranjería se aplica una norma nacional que no sea objeto de prueba (lo es la costumbre, el histórico en ocasiones y el derecho nacional no publicado).

Aunque si el actor no invocara el derecho extranjero aplicable que resulte de la norma de conflicto y fundamentase la demanda en el derecho del foro (silenciando así la aplicación del derecho extranjero al que remite la norma de conflicto) y el demandado no opusiera como excepción material la aplicación del derecho extranjero según la norma de conflicto limitándose a negar los hechos que aduce el actor o se limitara a alegar y fundamentar otras excepciones materiales conforme a la norma del foro, difícil le será al juez, como señalé, conocer esa situación y poder probar y aplicar de oficio ese derecho extranjero.

Ello es así al no exigirse que en la demanda —ni en el poder otorgado al procurador del actor- que tenga que constar expresamente la condición de extranjero del actor (o del demandado, en el poder y contestación de la demanda) de la que resulte la aplicación -conforme a dicha norma de conflicto- de la norma extranjera y aplicaría en tal caso el juez el derecho del foro por desconocer esa situación de que procede aplicar la norma extranjera conforme a la norma de conflicto. O no hacerse referencia a la situación del bien mueble reclamado o al lugar y forma del contrato cuyas obligaciones se reclamen.

E incluso de conocer el juez mediante su conocimiento privado que debe aplicarse de oficio una norma de conflicto - parece que no podría tampoco probar de oficio (como un hecho) esa norma incluso y pese a lo dispuesto hoy —en el art. 33-3 LCJIC-y aplicar de oficio la norma extranjera ante la pasividad de ambas partes. Con 
este sistema el carácter imperativo de la norma de conflicto (que exigiría la imposición de deber jurisdiccional coercible al juez y exigible por tanto de probar de oficio y aplicar de oficio ese derecho extranjero, lo que no se prevé ni en la LEC ni en la LOPJ), queda muy debilitado.

Por esto algunos llegan a considerar que la norma de conflicto que es por su redacción en apariencia indisponible e imperativa por lo que los tribunales deben aplicarla de oficio si así la aportan las partes en el proceso civil español; pero que se convierte en disponible por vía indirecta si las partes no la aportan en el proceso alegándola con lo que subsidiariamente se convierte en aplicable y de forma directa la ley del foro aunque forzándose sobremanera la interpretación a que responde el actual art. 33 LCJIC.

Con esta afirmación referido al sistema jurisprudencial establecido respondemos al sistema legal que siguiendo esa jurisprudencia estableció en 1974 la reforma del CC y que sigue vigente. El establecimiento de que el juez deba aplicar en todo caso de oficio la norma de conflicto y la extranjera sin necesidad de prueba pondría fin a esa situación, aunque lo razonable es que sólo lo fuera en el marco de la Unión Europea.

Esta reforma de 1974 venía precedida de una variada y complicada normativa. La Ley de Bases de la Jefatura del Estado N. ${ }^{\circ}$ 3/1973 de 17 de Mayo estableció, las Bases del nuevo Título Preliminar del Código Civil, previsto para insertarse en el texto originario de 1888-9. El Decreto Ley N. ${ }^{\circ} 7 / 1974$ de 5 de Abril, amplió el plazo para presentar el texto. Finalmente, el Decreto N. ${ }^{\circ} 1836 / 1974$ de 31 de mayo es el que sancionó con fuerza de ley el texto articulado del Título Preliminar del Código Civil.

En este sentido el artículo 12-6-2 CC del nuevo Título Preliminar tras la reforma recogió la jurisprudencia del TS sobre la necesidad y requisitos de la prueba del derecho extranjero respecto a su contenido, alcance e interpretación (según la doctrina legal de los altos tribunales o TS del país en cuestión), vigencia y medios de prueba admisibles. Y sobre todo se establece que la iniciativa probatoria del derecho extranjero (carga de su prueba) corresponde a la parte interesada en su aplicación como si de un hecho se tratara. Pero dicha prueba puede ser correspondida, completada o complementada por el órgano jurisdiccional de no obtenerse un resultado probatorio positivo de la actividad probatoria de la parte que asume tal carga al tratarse de la prueba del derecho, en este caso, extranjero. E incluso sustituida por el juez. 
No se trata de la prueba de un simple hecho, aunque se equipare en parte la prueba del derecho extranjero a la del hecho, ya que en el caso de hechos esa actividad del juez si los introduce de oficio fuera de la actividad de las partes -incluso siendo notorios- sería inadmisible puesto que afectaría a su parcialidad. Y si ya habían sido introducidos en el proceso esos hechos por las partes dicha iniciativa y actividad oficial probatoria del Juez se encuentra sujeta a varios límites según el objeto sea o no disponible, art. 282 LEC.

Puede hablarse por ello de una jurisprudencia del TS mayoritaria desde 1864 hasta 1974. Y de otra jurisprudencia del TS, ligeramente modificada y afectada desde 1974 hasta el momento presente. Resumimos esta jurisprudencia, aunque debemos dejar claro desde este momento que este no es un trabajo jurisprudencial y por ello no incorporo las sentencias correspondientes (señalando la fecha y su contenido literal) pues son muchas y excedería con mucho la extensión pensada para este trabajo. Pero remito a la fuente donde aparecen mencionadas y que aparece en la bibliografía citada al final del trabajo.

a) Siguiendo en parte a Alonso Cuevillas que hace un examen pormenorizado de la doctrina del TS al pronunciarse sobre los recursos de casación desde 1887 hasta 1974 en nuestra materia, ésta sería la siguiente en la forma que resumimos, (sin perjuicio de las indicaciones hechas anteriormente para la jurisprudencia anterior a 1887):

- La aplicación del derecho extranjero al caso concreto forma parte del principio iura novit curia, una vez probado y no antes. Se aplica, en su virtud, de oficio. (Después se confirmó por el art. $12-6-1^{\circ} \mathrm{CC}$ ).

- El derecho extranjero debe y necesita ser probado como una cuestión de hecho para poder ser aplicado, constituyendo esta actividad acreditativa del derecho extranjero auténtica actividad probatoria de las partes y bajo la iniciativa de la parte a la que corresponde probarlo siguiendo en principio la regla distributiva de la carga de la prueba para los hechos, del art. 1214 CC. Se equipara a un hecho su prueba, y puede estar exonerado de prueba ese derecho extranjero si es reconocida por ambas partes su existencia y contenido, como su aplicación jurisprudencial en el país de origen, y su vigencia o cuando tal derecho extranjero tenga el carácter de notorio para el órgano jurisdiccional (por su actividad jurisdiccional previa o su conocimiento privado). 
- El objeto de la prueba del derecho extranjero ha de ser sobre su existencia, contenido, vigencia. A esto se añade como es interpretado y aplicado por los órganos jurisdiccionales del país en cuestión según la jurisprudencia de sus órganos superiores o de su TS si lo tienen sobre todo en el sistema continental. Es decir, responde al principio probatorio de la prueba integral del derecho extranjero, en ciertos casos, para que nuestros órganos jurisdiccionales sepan su aplicación, en ese país extranjero, en casos análogos o idénticos. Debe hacerse por medio del dictamen debidamente legalizado y traducido de dos jurisconsultos del país en cuestión junto a otras pruebas.

- Corresponde la carga de la alegación y prueba del derecho extranjero a quien lo invoca para favorecerse de él como si de un hecho se tratara y conforme a las reglas de la carga en la iniciativa y distribución probatoria del art. 1214 CC. (Hoy 217 LEC)

- De no probarse el derecho extranjero por falta de iniciativa probatoria o si existiendo ésta no se alcanza el resultado probatorio positivo deseado sobre ese derecho extranjero, debe aplicarse subsidiariamente nuestro derecho nacional, es decir la Ley del foro. (Así se recoge actualmente en el art. 33LCJI).

Se dictaron sin embargo algunas sentencias absolutorias en la instancia que no se pronunciaron sobre el fondo del asunto por falta de prueba del derecho extranjero del actor como si dicha falta de prueba fuera un presupuesto procesal y denegándose por ello la tutela judicial solicitada por el actor, aunque sin producir esas sentencias el efecto de cosa juzgada material si no sólo el de cosa juzgada formal. (Véase la EM-V de la LCJI).

Incluso se dictaron algunas sentencias (afortunadamente muy pocas con lo que la corriente jurisprudencial no fue relevante) que eran desestimatorias en el fondo, de la pretensión del actor absolviendo al demandado al equiparar la falta de prueba del derecho con la falta de prueba de los hechos constitutivos afirmados por el actor que son el fundamento de su pretensión siempre dependiendo de la posición procesal adoptada (referida a hechos constitutivos o a los impeditivos, extintivos o excluyentes) y con plenos efectos de cosa juzgada material. (En este caso se deniega la justicia, mediante una sentencia injusta con efectos plenos de cosa juzgada material por tanto una solución peor que en el párrafo anterior en cuanto manifiestamente injusta). 
b) Con la reforma del CC en 1974 que incorpora el Título preliminar y en éste el artículo $12-6-2^{\circ}$, dicha jurisprudencia a partir de esa fecha y diríamos que hasta la actualidad ha sido objeto de las siguientes precisiones o cambios respecto a la anterior:

- La norma extranjera no puede ser tratada exclusivamente como una cuestión de hecho. Por ello la actividad acreditativa del derecho extranjero no constituye únicamente actividad probatoria pues corresponde al juez aplicar el derecho extranjero al caso concreto, una vez probado.

- Existe un derecho de las partes a la prueba del derecho extranjero (que no siempre sería una carga, aunque ello no queda del todo claro al tratarse de una sentencia aislada). No estaríamos ante una carga (procesal y subjetiva de la parte) como antes en el sentido de James Goldschmidt (de considerarse el proceso una situación o conjunto de situaciones jurídicas en vez de una mera relación jurídica entre las partes para con el juez y de éste para con ellas, siempre según su crítica a la teoría del proceso como relación jurídica plasmada en su obra -que traduzco libremente del alemán al español- el proceso como situación jurídica. Una crítica a la teoría del proceso como relación jurídica publicada en Berlín en 1925) si no de un derecho potestativo en términos procesales o de una mera facultad procesal subjetiva de la parte que no implica una propia carga al no provenir de la parte a quien incumbiría su prueba, si no de un deber jurisdiccional —en nuestro caso- incoercible del juez.

- El derecho extranjero puede acreditarse o probarse por cualquier medio de prueba practicado de los admitidos en derecho; sin que tenga que serlo únicamente - como antes establecía la jurisprudencia mayoritaria del TS - por el dictamen emitido por dos jurisconsultos del país en cuestión. Y están sujetos tales medios de prueba practicados a la libre valoración, conforme a las reglas de la sana crítica (así hoy el art. 33-2 y 4 de la vigente LCJIC) sin vincular al órgano jurisdiccional.

- Puede igualmente acreditarse en exclusiva según el TS (o junto a otros medios de prueba) con el informe emitido (en documento público, certificado y con todas las garantías formales a las que hoy se refieren los art. 34 y 35 de la vigente LCJIC y demás concordantes) y donde consta el derecho extranjero cuya información se solicitó, expedido por el órgano que está obligado a ello en virtud de los acuerdos y tratados interna- 
cionales suscritos por España (bilaterales o multilaterales) sobre cooperación y colaboración de información del derecho extranjero. (Hoy, art 34 y 35 vigente LCJIC).

Por cierto, la vigente LCJIC parece otorgar el mismo valor probatorio a ambos medios probatorios es decir al dictamen de los juristas $\mathrm{y}$ al informe de derecho extranjero de la autoridad competente (art. 33-2 y 4 LCJI). Aunque no debemos olvidar que se trata el segundo de un documento público equivalente a una certificación otorgado con todas las garantías formales y por esto sujeto a las reglas de valoración legal del documento público extranjero de la LEC... salvo que esta hubiera sido derogada lo que niega el art. 33.1 LCJI y que entonces debería valorarse conforme al art. 33.1 LCJIC según lo hace la LEC para el documento público.

Por lo que parece dudoso que si no se impugna u opone la falsedad de este documento público deje de estar sujeto a la prueba legal y tenga que prevalecer la libre apreciación de su prueba por el juez, aunque se encuentre sometido en cuanto a su valoración a las reglas de la sana crítica (máximas de la experiencia, del criterio racional o humano, de la lógica según el art. 33-2 y 4 LCJI y que tendrá que especificar el juez al motivar la sentencia «para destruir el valor de esa prueba legal» lo que parece a todas luces que no tiene sentido ¿…......?.

— En su virtud, según el TS, los órganos jurisdiccionales pueden y quizá deberían como facultad (obsérvese que la LJCIC no llega a acuñar el término deber como tampoco la jurisprudencia del TS surgida desde 1974) colaborar, complementar y completar con las partes esa la labor de acreditación y práctica de la prueba del derecho extranjero; también pueden o deberían (recalco que no se acuña el término deber jurisdiccional en sentido imperativo aunque fuera un "simple deseo" y por ello no sancionable) de oficio acordar la práctica de los medios de prueba tendentes a que el resultado de la prueba del derecho extranjero resulte positivo, existiendo además una facultad del juez, no sancionable al no ser un deber imperativo, de investigar de oficio el derecho extranjero invocado y no probado para poderlo aplicar. (Se mantuvo esta línea después en los vigentes art. 281-2 LEC y 33 LCJIC).

- El juez está obligado a aplicar de oficio la norma de conflicto (art. 12-6- $1^{\circ} \mathrm{CC}$ ) que resulte de los autos. Y así aplicará el derecho extranjero al que remite ésta, si resulta probado por las partes, o él lo comprueba de oficio. Sin iniciativa probatoria 
alguna de las partes, desde 1974 se admite por el TS en alguna sentencia que el juez está facultado para probarlo de oficio (cabe la iniciativa probatoria oficial del juez en el ámbito de las normas de derecho extranjero que se refieran a derechos subjetivos sean estos disponibles o no. (Y que después estableció la LEC 2000, art. 281-2 y 282).

- Si el Juez conoce la existencia y contenido del derecho extranjero por su conocimiento privado (estudios de especialización universitaria en derecho comparado, estancias universitarias en ese país, curiosidad por el derecho del país en cuestión....) o la existencia y contenido de ese derecho le es notorio por su actividad jurisdiccional previa al haberlo aplicado con anterioridad en casos semejantes, puede aplicarlo de oficio sin necesidad de actividad previa probatoria de las partes si están conformes con ello; aunque si estuvieran dispuestas a asumir la iniciativa probatoria lo habrán hecho antes. Pero, si desplegada esta actividad probatoria por las partes no llevó a un resultado probatorio positivo sobre su existencia, contenido, vigencia o aplicación del derecho extranjero (por los tribunales del país en cuestión) si el juez de oficio lo conoce en ambos supuestos puede aplicarlo de oficio sin necesidad de prueba.

- Si las partes a pesar de su iniciativa probatoria no consiguieron probar el derecho extranjero por la inadecuación de la prueba propuesta, por causas de fuerza mayor o caso fortuito, por la no colaboración de las personas obligadas en su práctica (testigos, informe de autoridades, defectos en la cédula de citación....), el juez puede colaborar, cooperar o ayudar a las partes en la ulterior realización de la misma; o asumir esta de oficio para que esas personas obligadas desplieguen esa actividad. Art. 12-6-2 CC (y después art. 281.2 LEC). O manifestarles que lo conoce de forma privada para aplicarlo de oficio sin necesidad de prueba.

- Si pese a la iniciativa adecuada de las partes el derecho extranjero no quedó probado, o si no lo fue por falta de iniciativa probatoria de las partes o por iniciativa inadecuada de ellas el juez puede desplegar esa actividad oficial (art. 12-6-2 CC y desde el 2000, art 281-2 LEC) que repito no se le prohíbe para después poder aplicar el mismo de oficio o no desplegarla si conoce privadamente dicho derecho.

- Pero como tampoco se le obliga al órgano jurisdiccional a tener que probar de oficio ese derecho extranjero en caso de 
falta de iniciativa probatoria de las partes, o de insuficiencia en la iniciativa de las mismas o cuando siendo adecuada y suficiente en principio la de éstas (o la oficial del juez) no se consigue el resultado probatorio positivo para que se tenga por probado tal derecho por causas ajenas a las partes (o al juez) se permite al juez que sin tener que probar de oficio y de nuevo el derecho extranjero (para su aplicación ulterior), pueda sin más aplicar el derecho nacional, es decir la ley del foro, a ese caso concreto.

Sin embargo resulta que en este supuesto la jurisprudencia del TS (y actual LCJIC, en su Exposición de Motivos V y art. 33) para llegar a la solución de no aplicar el derecho extranjero por falta de prueba y en su lugar aplicar la lex fori, exige que concurran situaciones o circunstancias especiales o excepcionales que hacen imposible o muy difícil la prueba del derecho extranjero aunque no se especifican o manifiestan con carácter general enumerativo o a título de ejemplo, ni en esa EM-V, ni en el art. 33, ni en esa jurisprudencia del TS por lo que deberían motivarse en la sentencia del caso concreto si en ella se aplica la lex fori o nacional.

Esto parece de toda lógica. Pues de lo contrario por esta vía indirecta de la falta de resultado positivo probatorio del derecho extranjero en la iniciativa asumida por las partes (o del juez) se vaciaría de contenido el art. 12-6-1 CC que exige que la norma de conflicto se aplique de oficio si resulta del contenido de los autos y por tanto que se aplique el derecho extranjero al que remite, siempre que sea posible.

De lo contrario se aplicaría en su lugar con carácter más o menos general la lex fori o nacional volviéndose de nuevo al sistema histórico anterior a 1855, ya estudiado. Es decir, a considerar los derechos del extranjero en clave de extranjería y no en clave conflictual sobre todo para jueces poco diligentes (o con escasos conocimientos jurídicos, como son los jueces de Paz, a los que no se les pueden exigir otros de mayor medida) en asumir la iniciativa probatoria oficial del derecho extranjero (pese a lo dispuesto en la vigente LCJIC, art 34 y 35) y sobre todo para los jueces cómodos que no la asumen al entender que la carga probatoria debe ser exclusiva de las partes y que la facultad jurisdiccional (que no deber sancionable) de asumir esa iniciativa oficial no va con ellos al serles mucho más cómodo aplicar la lex fori o nacional.

- Si no desea el Juez asumir la iniciativa probatoria oficial del derecho extranjero ante la falta de prueba de éste por las par- 
tes para que el caso no quede imprejuzgado y se deniegue la tutela judicial efectiva a las partes consagrada en el art. $24 \mathrm{CE}$ de 1978 es decir, la tutela judicial efectiva —en los términos del derecho internacional privado- (a que se refiere la EM de la vigente LCJIC y su art. 33, aunque debió establecerse que sólo de forma subsidiaria, ante la imposibilidad o suma dificultad de la prueba del derecho extranjero bajo su iniciativa oficial aunque no fuese desplegada por las partes y motivándose adecuadamente en la sentencia), aplicará la ley del foro o nacional.

Debió establecerse como última opción de carácter excepcional y motivarse debidamente en la sentencia la aplicación de la lex fori cuando la iniciativa oficial del juez (tras la de las partes, o con la de éstas e incluso sin la de ellas) en la actividad probatoria para acreditar el derecho extranjero no produjera el resultado probatorio positivo pese a su debida diligencia y no quedara otro remedio que aplicar la norma nacional. (Y así lo hubieran regulado después el art. 281-2 LEC y 33-3 LCJIC. La excepcionalidad de la EM de la LCJIC y su art. 33-3 resulta fuera de este contexto señalado, al tratarse de una «mera» afirmación formal de intenciones que poco añade y deja algo vacío de contenido al art. 12-6-1 CC).

$\mathrm{Al}$ no hacerse así ni en la reforma del título preliminar del CC en 1974, ni en la de la vigente LEC 2000, ni sobre todo en 2015 en la LCJIC el sistema corre el riesgo - al no imponerse una obligación jurisdiccional sancionable al juez de asumir la iniciativa probatoria oficial del derecho extranjero para su ulterior aplicación y sin las sanciones oportunas derivadas de esta manifestación que lo es de la función jurisdiccional y que se refieren el art. 1, 9 y 117 CE; 1 y ss. LOPJ; y 1 CC. Es decir, juzgar y ejecutar lo juzgado conforme a la norma material establecida que puede quedar vaciada de contenido.

$\mathrm{Al}$ seguir siendo una facultad del órgano la prueba o acreditación del mismo (art. 281-2 LEC y 33-3 LJCI) puede quedar desvirtuado o sin contenido el art. 12-6-1 CC; y así que la aplicación de la norma de conflicto y la del derecho extranjero a que remite sea una entelequia y se sustituya indirectamente por la aplicación más o menos general de la norma material nacional o lex fori.

Disponía el art. 12-6-2 CC:

«La persona que invoque el derecho extranjero deberá acreditar su contenido y vigencia por los medios de prueba admitidos en la ley española. Sin embargo, para su aplicación, el juzgador podrá valerse además de cuantos instrumentos de averiguación considere necesa- 
rios, dictando al efecto las providencias oportunas». (Recalco que dice podrá y no deberá, como el art. 281, de la LEC 2000).

\section{LEGISLACIÓN DEL PERIODO CONSTITUCIONAL}

Como hitos legislativos posteriores debe mencionarse la Constitución Española, de 6 de Diciembre, de 1978 (publicada en el BOE de 29 de Diciembre, y con vigencia desde la misma) en especial sus artículos 24 referido a las partes y los art. 117 y ss. de la misma referidos a la jurisdicción. Sin olvidar el art. 1 y 9 de la misma respecto a la consagración del principio de legalidad y los artículos 14 y ss. sobre protección de derechos fundamentales entre los que se encuentra el art. 24 referido al derecho a la tutela judicial efectiva y a las garantías procesales atinentes al derecho de defensa y la prohibición de la indefensión. Así como la legislación complementaria reguladora del Tribunal Constitucional y sus funciones, sobre todo la LO 2/ 1979 de 3 de octubre. BOE 239 de 5-10-1979.

Existe una sentencia del TC sobre la prueba del derecho extranjero referida al derecho a la tutela judicial efectiva y referida a los medios de prueba solicitados para probar el derecho extranjero que a los efectos de la indefensión no añade nada nuevo a la jurisprudencia establecida del TS. Se desaprovechó en esta sentencia la oportunidad de una posible creación jurisprudencial del TC que complementara la del TS en las muchas cuestiones que plantea la prueba del derecho extranjero, siquiera como obiter dicta. Pero sin olvidar que el TC no es un tribunal para controlar al TS salvo en lo que afecte -respecto a sus sentencias - a la constitucionalidad de las normas aplicadas, qué en el caso, en cuestión, no se daba.

En 1984, se reforma la primitiva LEC de 1881 por la Ley 34/1984 de 6 de Agosto (BOE 188 de 7 de Agosto 1988)) que modificó el art. 340 LEC y en lo que a nosotros respecta debe ponerse este precepto en relación con el art. $12-6-2^{\circ} \mathrm{CC}$, al referirse a las facultades de dirección oficial del juez en el proceso respecto a la prueba, ya en la fase de conclusión, después de practicarse aquélla. Se le permite acordar como mejor proveer - añadiéndose a los supuestos del primitivo artículo en su redacción original- que se traigan documentos a la causa, preguntar a las partes y testigos y traer otros autos relacionados con el pleito. Ello podía ser de interés en la prueba del derecho extranjero.

Además, establece (cubriendo la laguna legal) que no cabe recurso contra la resolución que las acuerda. Y qué tras su práctica, en aras 
del derecho de defensa, debe oírse a las partes para que concluyan por escrito sobre su resultado. (Sobre este particular véase, Martín Ostos, J. Las diligencias para mejor proveer. Madrid.1981).

Este precepto pensado para la prueba de los hechos en la fase conclusiva del proceso (tras la práctica de la prueba, repito) no excluía expresamente la prueba del derecho extranjero en fase conclusiva cuando la practica anterior de su prueba no lleva o conduce a un resultado positivo (no queda probado el derecho extranjero) por las razones que fueran y por ello era un complemento del art. 12-6-2 CC pensado para la fase probatoria. Aunque la jurisprudencia menor de nuestros jueces y tribunales no utilizó apenas la vía que el art. 340 LEC ofrecía de complemento al art. 12-6-2 CC.

La Ley Orgánica del Poder Judicial. Ley Orgánica 6/1985, de 1 de Julio sobre todo en su Título Preliminar y sus Libros I y IV completa las disposiciones de la CE referidas al Poder Judicial.

\section{LA LEC 2000}

El año 2000, la LEC de 1881 fue sustituida por la vigente Ley 1/2000, de 7 de Enero, de Enjuiciamiento Civil. En el artículo 281-2 se ocupa de la prueba del derecho extranjero recogiendo un contenido semejante a la del derogado art. $12-6-2^{\circ} \mathrm{CC}$, pero sin señalar expresamente que la prueba del derecho extranjero sea una carga de la parte que lo alega quien deberá probarlo como hacía el art. 12-6-2 ${ }^{\circ} \mathrm{CC}$ texto de 1974. Aunque resulta implícita si se compara con el art. 281-1 LEC referido a la carga de la prueba de los hechos y que resalta el art. 33 LCJIC.

Dispone el art 281-2 referido al objeto y necesidad de la prueba, inserto en el Libro II (de los procesos declarativos), Título I (De las disposiciones comunes a los procesos declarativos), Capítulo V (De la prueba: disposiciones generales), Sección primera (Del objeto, necesidad e iniciativa de la prueba) en su párrafo segundo:

Objeto y necesidad de la prueba.

2. «También serán objeto de prueba la costumbre y el derecho extranjero. La prueba de la costumbre no será necesaria si las partes estuviesen conformes en su existencia y contenido y sus normas no afectasen al orden público. El derecho extranjero deberá ser probado en lo que respecta a su contenido y vigencia, pudiendo valerse el tribunal de cuantos medios de averiguación estime necesarios para su aplicación». 
En cuanto a la estructura del precepto y a su incardinación legal se ha criticado que el artículo 281 se refiera tanto a la prueba de los hechos como a la prueba del derecho. Debió referirse el art. 281 sólo a la prueba de los hechos con el contenido de sus numerales 1, 3 y 4 .

Y a la prueba del derecho debió dedicársele un precepto independiente posterior, quizá el siguiente (el 282 aunque se refiere a otro aspecto que pudo incluirse en el 281 como numeral 5). O entre ambos introducir un artículo $281 \mathrm{Bis}$, si se produce una reforma posterior en tal sentido. Por tanto, el número del artículo dependería de la estructura (según fuese la originaria o la sobrevenida a consecuencia de una reforma). Aunque es cierto que el artículo 281 distingue entre la prueba de los hechos y derecho en párrafos y numerales distintos, lo cual no obsta a que la prueba de los hechos y la del derecho como veremos en este trabajo responden a principios muy diferentes y por ello deben regularse en diversos preceptos.

Es a dicho art. 12 del $\mathrm{CC}$ en los numerales vigentes y al artículo 281-2-2 LEC 2000 a los que me he referido a lo largo de este trabajo donde destaco que son el fruto de la jurisprudencia del TS que se introdujo como derecho positivo.

\section{LA LEY 29/2015 DE 30 DE JULIO DE COOPERACIÓN JURÍDICA EN MATERIA CIVIL}

Es la más reciente y última norma que cierra esta evolución histórica. A la prueba del derecho extranjero dedica la Exposición de Motivos el ordinal latino $\mathrm{V}$ y el artículo 33 que ya fueron insertados. Remisión a la LEC y demás disposiciones aplicables (párrafo 1). Valor probatorio de la prueba practicada según las reglas de la sana crítica (párrafo segundo). Con carácter excepcional si no pudo acreditarse el contenido y vigencia del derecho extranjero por las partes puede aplicarse el derecho español. (Párrafo tercero). Los informes y dictámenes sobre el derecho extranjero no tienen carácter vinculante para los órganos jurisdiccionales españoles. (Párrafo cuarto). Recoge la jurisprudencia del TS insertada en un precepto de derecho positivo.

Esta LCJIC, según el art. $33-2^{\circ}$ y $4^{\circ}$ se aparta respecto a la valoración de la prueba del derecho extranjero, de la que establece la LEC, en cuanto a la valoración legal del documento público extranjero, (con carácter general) que lo somete a la libre apreciación de acuerdo con las reglas de la sana crítica. Lo que supone que la LCJIC art. 33-2 ${ }^{\circ}$ y $4^{\circ}$ sienta una excepción a la prueba legal establecida en la LEC para 
el documento (aunque habla de informes — que serán documentales- para informar del derecho extranjero) pese a la rotundidad de su párrafo primero que sienta lo contrario manifestando su conformidad con el sistema de la LEC que no se reforma, como también proclama en su EM-V. Parece extraño además que la prueba del derecho, a diferencia con la prueba de los hechos, se encuentre sometida a las reglas de la sana crítica siempre pensadas para prueba de hechos y no del derecho. La jurisprudencia del TS o la menor nos dirá en lo que consisten esas «reglas».

Igualmente los artículos 34 y 35 LCJI ya trascritos y que por ello no repetimos se refieren a la información del derecho extranjero, informes públicos documentales emitidos por las autoridades competentes del Estado en cuestión y que certifican con todas las garantías formales el contenido, vigencia y como es interpretado por los jueces y tribunales del Estado en cuestión el derecho extranjero y que se supone que se convertirán en el futuro, vigente ya LCJIC (si funciona adecuadamente para el logro de la tutela judicial civil internacional), en el medio más común e idóneo para probar el derecho privado extranjero, dentro de ese ámbito de su art. 1.

\section{CONCLUSIONES}

\section{Primera}

Deben destacarse dos periodos. El primero en su cronología temporal se corresponde con la aplicación exclusiva del derecho nacional privado del foro, en el proceso civil seguido en España ante nuestros jueces y tribunales, cualquiera que sea su instancia, para todo supuesto en que concurre el elemento de extranjería.

Así como el no reconocimiento de toda sentencia civil dictada en el extranjero en que se aplicó dicho derecho como regla general (aunque en lo mercantil existen casos en que si se reconocían por la jurisdicción consular o incluso se llegaba a aplicar el derecho mercantil de otros países) por lo que a este fin había que iniciar un nuevo juicio civil en España. Va desde los albores legislativos hasta las fechas de 1855 y 1864.

El segundo y sucesivo en el tiempo se corresponde con la aplicación exclusiva del derecho extranjero en el proceso civil seguido en España ante nuestros jueces y tribunales cualquiera que sea la instancia de concurrir el elemento de extranjería y que es decisivo en clave conflictual merced a la doctrina legal del TS establecida desde 1864. 
Y también se corresponde con el juicio de reconocimiento de las sentencias y decisiones extranjeras firmes por nuestros jueces y tribunales desde 1855 cuya competencia inicial era exclusiva del TS.

\section{Segunda}

Dada la parca regulación legal del juicio de reconocimiento de sentencias extranjeras en España en las LEC de 1855 y 1881, este tuvo que ser desarrollado y completado con la doctrina legal del TS al pronunciarse sobre este juicio en los distintos autos dictados a este objeto.

La fecha de 1864 corresponde a la primera STS que se pronuncia sobre la alegación, prueba y aplicación del derecho extranjero por nuestros jueces y tribunales en los procesos ante ellos seguidos en España y admite por primera vez la vieja doctrina estatutaria. Esta jurisprudencia colmó totalmente una laguna legal por la falta de su regulación en un cuerpo material.

Esto se debió a que, en nuestro país, primero en el orden jurisdiccional civil (no así en lo mercantil, pues el C de C es de 1829 y la LENC es de 1830)) se abordó la legislación procesal en 1855 y treinta y cuatro años después (1889), la sustantiva. De todas formas, las reformas legislativas materiales y procesales de 1889 (CC), 1974 (Título Preliminar CC), 2000 (LEC 2000) y 2015 (LCJIC) se limitaron a recoger en preceptos legales la doctrina legal establecida por el TS, y al margen de esta doctrina legal fueron muy poco creativas e innovativas dichas normas reguladoras de la cuestión.

\section{BIBLIOGRAFÍA}

ABel Lluch, X. Configuración de las reglas de la sana crítica en la Ley 1/2000 de Enjuiciamiento Civil. Revista Vasca de Derecho Procesal y Arbitraje. Vol. 25. 2013. Pág. 135-166.

- Iniciativa probatoria de oficio en el proceso civil. Barcelona. 2005.

- (con Pico Junoy, J) La iniciativa probatoria del juez civil: a propósito de un caso. Los poderes del juez en materia probatoria. Seminario de estudio de la escuela judicial. Barcelona. 2003. Pág. 137174.

- Las diligencias finales de oficio del artículo 435-2 LEC. La Ley 2003-5. Pág. 1735-1741- 
- Los medios de prueba a la luz de las reglas de la sana crítica. La Ley. N. ${ }^{\circ} 8659.2015$.

— Repensando el concepto de documento. La Ley. N. ${ }^{\circ} 7667.2011$.

Acedo Rico y Rodríguez, J. (Conde de la Cañada). Apuntamientos prácticos para todos los trámites de los juicios civiles así ordinarios como extraordinarios que se empiezan, continúan y acaban en los Tribunales Reales. T. Madrid. 1793. Las ediciones de 1794 y de 1845 aparecen con el título de Instituciones Prácticas de los juicios civiles, así ordinarios como extraordinarios, en todos sus trámites según que .......

Adán Domenech, F. Consecuencias de la falta de prueba del derecho extranjero. En Práctica del Derecho Extranjero. Director Pico Junoy, J. La Ley. Madrid. 2011.

Aguilar Benítez de Lugo, M. Comentarios al artículo 12 del Código Civil. Comentarios al Código Civil dirigido por Paz Ares, C; Bercovitz, R; Díez Picazo, L; Salvador Coderch, P. Ministerio de Justicia. T. I. 1991. Madrid. Pág. 139-150.

- La ausencia de prueba del derecho extranjero. Justicia. 1989. Pág. 73-139.

- La prueba del derecho extranjero ante los Tribunales Españoles. RGD. 1989. N..$^{\circ}$ 541-542. Pág. 6247 y ss. Y 6314 y ss.

- Los problemas de la aplicación de la norma de conflicto. Una concepción internacionalista y funcional. Pacis Artes. Obra homenaje al profesor Julio D. González Campos. T. II. Derecho Internacional Privado, Derecho Constitucional y vario. U.A.M. Madrid. 1985. Pág. 1117-1137.

Aguilar Navarro, M. Derecho Internacional Privado. Vol. I. T. I. Introducción y fuentes. Facultad de Derecho. Universidad Complutense. Madrid. 1976. Vol. I. T. II Parte segunda. Madrid. 1975.

- Observaciones críticas en torno a la historia del Derecho Privado Internacional. Anales de la Universidad Hispalense. Vol. XIX. Sevilla. 1959.

Almagro Nosete, J. El «libre acceso» como derecho a la jurisdicción. Revista de la Facultad de Derecho de la Universidad de Madrid. Vol. 14. N. ${ }^{\circ}$ 37. 1970. Pág. 95 a 140.

- Garantías constitucionales del proceso civil. Justicia. 1981-1. Pág. 11-42. Y en Constitución, derecho y proceso. Estudios en me- 
moria de Vicente Herce Quemada y Ángel Duque Barragués. Zaragoza. 1983.

- La prohibición constitucional de la indefensión. Poder Judicial. N. o 6. Extr. 1989. Pág. 231-246.

Alonso Cuevillas Sayrol, J. Las normas jurídicas como objeto de prueba. Tratamiento del derecho extranjero y de la costumbre en el proceso civil español. Valencia. 2004.

ÁlvAREz GonZÁLEz, S. La aplicación judicial del derecho extranjero bajo la lupa constitucional. REDI. Vol. LIV. 2002-1. Pág. 205 y ss.

- Aplicación judicial del derecho extranjero: la desconcertante práctica judicial, los estériles esfuerzos doctrinales y la necesaria reforma legislativa. La Ley. 4-7-2005.

ÁlVAREZ-VALDÉs VALDÉs, M. La extranjería en la historia del derecho español. Universidad de Oviedo. Servicio de Publicaciones. Oviedo. 1992.

- Evolución del estatuto del extranjero en el derecho histórico español. Universidad Complutense. Madrid. 2003.

ANGUlo Rodríguez, M. El derecho extranjero y su tratamiento procesal en España. Estudios de Derecho Internacional Público y Privado, homenaje al profesor Luís Sela Sampil. T. II. Oviedo.1970. Pág. 967 y ss.

AzParRen Lucas, A. Nuevas perspectivas del papel del Juez frente a la aplicación judicial del derecho extranjero. Consejo General del Poder Judicial. Cuadernos de Derecho Judicial. Madrid. 1998. Pág. 199-230.

BARBOSA MoreIRA, J.C. Breves reflexiones sobre la iniciativa oficial en materia de prueba. Libro homenaje a Jaime Guasp. Granada. 1984.

Blanco López, C. Comentario al artículo. 281. Comentario a la nueva Ley de Enjuiciamiento Civil. Coordina. Lorca Navarrete, A.M. Valladolid. Pág. 463-484.

Bonet Ramón, F. Comentario de Jurisprudencia del Tribunal Supremo. Revista de Derecho Privado. 1941. pág. 35 y ss.

Borras Rodríguez, A. Comentario al artículo 12 del Código Civil. Comentarios al Código Civil dirigido por Paz Ares Rodríguez, C; Bercovitz, R; Díez Picazo, L; Salvador Coderch. T. I. 1991. Ministerio de Justicia. Pág. 139-150. 
EVOLUCIÓN HISTÓRICA DE LA APLICACIÓN DEL DERECHO EXTRANJERO...

Bouza Vidal. Comentario al artículo. 12-2 Código Civil. Comentarios al Código Civil y Compilaciones forales. Dirigidos por Albaladejo, M. Tomo I. Madrid. 1995

CABAÑas GaRcía, J.C. La valoración de las pruebas y su control en el proceso civil. Estudio dogmático y jurisprudencial. Madrid. 1992.

- Tratamiento de la carga de la prueba en el proceso civil. Actualidad Civil.1996-2. Pág. 349 y ss.

Calamandrei, P. La casación civil. Traduce Santiago Sentís Melendo. 3.Vol. Buenos Aires. 1945.

Calvo Caravaca, A.L. Comentario al artículo 12-5 Código Civil. Comentarios al Código Civil y Compilaciones Forales. Dirigidos por Albaladejo, M. Tomo I. Madrid. 1995.

Calvo Caravaca, A.L; Carrascosa González. Aplicación del derecho extranjero en España y la nueva Ley de Enjuiciamiento Civil. Tribunales de Justicia. N. ${ }^{\circ}$ 11. Pág. 1115-1170. Noviembre. 2000.

- La prueba del derecho extranjero en la nueva ley Española de Enjuiciamiento Civil 1/2000. La Ley. N. . 6178. 2005

- Norma de conflicto, aplicación del derecho extranjero en España y la nueva Ley de Enjuiciamiento Civil. Anuario Español de Derecho Internacional Privado. N. ${ }^{\circ}$ 1. 2001, Pág. 215-237.

CAPELETTI, M. El tratamiento del derecho extranjero en el proceso civil italiano. En Las sentencias y las normas extranjeras en el proceso civil. Traduce Santiago Sentis Melendo. Buenos Aires. 1968.

CARnelutti. La prueba civil. Buenos Aires. 1982. (Es la traducción de la obra originaria italiana de 1915).

CARballo Piñeiro, L. El carácter imperativo de la norma de conflicto y la prueba del derecho extranjero. Anuario Español de Derecho Internacional Privado. N. ${ }^{\circ} 1$ pág. 483-503. 2001.

CARRILlo Pozo, L.F. Una doctrina constitucional sobre la alegación y prueba de la ley extranjera. A propósito de la STC 33/2002 de 11 de Febrero. Aranzadi Social. 2003-8.

CARRILlo SAlCEDo, J.A. ¿Alegación y prueba del derecho extranjero por las partes o aplicación de oficio por el juez español de la norma de conflicto española? REDI. Vol. XIV-3. 1961.Pág. 585 a 601.

- Comentario al artículo 12-6 del Código Civil. Comentarios al Código Civil y Compilaciones Forales dirigidos por Albaladejo, M. Tomo I. Jaén. Edersa. 1978. 
Cerrato Guri, E. El onus probandi del derecho extranjero. En Práctica del derecho extranjero. Director Pico Junoy, J. Pág. 75 y ss. La Ley. Madrid. 2011.

- La prueba del derecho extranjero: un problema que sigue sin resolverse. Justicia. 2016-I. Pág. 303-334.

Corriente CóRdoba, J.A. En torno a la aplicación de la ley extranjera en el Derecho Español. RGLJ. 1974-

Cortés Domínguez, V. Derecho Procesal Civil Internacional. Madrid. 1981.

- El juicio ejecutivo por título extranjero y la aplicación del derecho extranjero. Justicia. 1984-3. Pág. 563-568.

Cremades Morant. Comentario al artículo 281 LEC. Coordina Marina Martínez Pardo, J. Pág. 701-2.

Cuartero Rubio, M.V. Prueba del derecho extranjero y tutela judicial efectiva. Derecho privado y Constitución. N. ${ }^{\circ}$ 14. 2000. pág. 21-71.

Damián Moreno, J. Los Jueces de Paz. Madrid. 1987.

D’Ors y Pérez-Peix, A. Derecho Privado Romano. Pamplona. 2004.

- El Código de Eurico. Madrid. 1960.

- La territorialidad del derecho visigodo. Estudios visigóticos. Roma-Madrid. 1956. Pág. 91-124.

EsCUdero LóPEZ, J.A. Curso de historia del derecho. Fuentes e instituciones político administrativas. Madrid. 2003.

EsParza LeIBAR, I. El dictamen de peritos en la Ley 1/2000 de Enjuiciamiento Civil. Valencia. 2000.

ESPINAR VICENTE, J.M. Algunas consideraciones en torno al desarrollo histórico del Derecho Internacional Privado en la Grecia de las ciudades. Rev. Der. Priv. 1981. Pág. 547-568.

- El marco constitucional del Derecho Internacional Privado Español. Constitución y relaciones privadas. (Dir. Ocallagham Muñoz, X). Cuadernos de Derecho Judicial. Madrid. 2003. Pág. 11 y ss.

Esplugas Mota, C. El Derecho Internacional privado y la nueva Ley Española de Enjuiciamiento Civil de 7 de Enero de 2000. Rev. Der. Int. Priv y Proc. 2001. Pág. 279-320.

ETXEBERRÍA GURIDI, J.F. Las facultades judiciales en materia probatoria, en la Ley de Enjuiciamiento Civil. Valencia. 2003. 
FAIRÉN GUILLEN, V. Notas sobre el valor de la jurisprudencia. Rev. Crítica Derecho Inmobiliario. N. ${ }^{\circ}$ 51. 509. 1975. Pág. 797-874.

- Sobre la recepción del recurso de casación francés. ADC. Vol. 10. N. 3. 1957. Pág. 661-692.

Fenech Navarro, M. (Con Carreras Llansana, J). La función del juez en la dirección del proceso civil. Estudios de Derecho Procesal. Barcelona. 1962.

- Derecho Procesal Civil. Madrid. 1980

FERNÁNDEZ URZAIQUín. Comentarios al artículo 281. (coordina Fernández Ballesteros, M.A; Rifá Soler, J.M: y Valls Gombau, M). Comentarios a la nueva Ley de Enjuiciamiento civil. Vol. 2. Barcelona. 2000.

Fernández Rozas, J.C. Comentario al artículo 12-6 del Código Civil. Comentarios al Código Civil dirigido por Paz Ares C; Bercovitz, R; Díez Picazo, L; Salvador Coderch, P. Tomo I. Ministerio de Justicia. Pág. 139-150. Madrid. 1991

- Comentario al artículo 12-4 y 12-6 del Código Civil. Comentarios al Código Civil y Compilaciones Forales Dirigidos por Albaladejo. Tomo I. Madrid. 1995.

Figueruelo Burrieza, A. El derecho a la tutela judicial efectiva. Madrid. 1989.

FONT I MAS, M. La aplicación del derecho extranjero resultante de la remisión de las normas de conflicto. En Práctica del derecho extranjero. Director Pico Junoy, J. Pág. 50 y ss. La Ley. Madrid. 2011.

FonT SERRA, E. El dictamen de peritos en la nueva Ley de Enjuiciamiento Civil. Cuadernos de derecho judicial. N. ${ }^{\circ}$ 7. 2000. Pág. 67-110.

- El dictamen de peritos y el reconocimiento judicial en el proceso civil. Madrid. 2000.

- La prueba de peritos en el proceso civil español. Barcelona. 1975.

FRAGUAS MASIP, R. Las excepciones a la aplicación del derecho material extranjero normalmente reclamado. Estudios sobre el Título Preliminar del Código Civil. T. II. Pág. 367-444. Jaén.1977.

Furno, C. Tratado de la prueba legal. Traduce Sergio González Collado. Madrid. 1954.

GaRAu Sobrino, F. La prueba del derecho extranjero en la nueva Ley de Enjuiciamiento Civil. RGD. N. ${ }^{\circ}$ 678-679. 2001. Pág. 2343-2366. 
Garberí Llobregat, J. Comentario al artículo 281.Los procesos civiles. T.III. Barcelona.2001. Pág. 8 y ss.

- La invocación formal del derecho vulnerado y el recurso de amparo constitucional. Rev. Der. Proc. 1988-2. Pág. 459 y ss.

- La prueba civil. Valencia. 2004.

García Gallo, A. La territorialidad de la legislación visigótica. AHDE. XIV. 1942-43. Pág. 593-609.

- Manual de historia del derecho español. 2.Vol. Madrid. 1984.

- Nacionalidad y territorialidad del derecho en la época visigoda. AHDE. T. XIII.1936-41. Pág. 168-264.

García GARRIDO, M. Derecho privado romano. Madrid. 2005.

GaRCIMARTín ALFÉREZ, F.J. La argumentación más favorable al Derecho Fundamental, el acceso a los recursos y las decisiones judiciales extranjeras. (A propósito de la STC 199/1994 de 4 de Julio). Derecho Privado y Constitución. N. ${ }^{\circ}$ 5. 1995. Madrid, Pág. 329-352.

- La interpretación más favorable al Derecho Fundamental. El derecho a la tutela judicial y el recurso de amparo. Derecho privado y Constitución. N. 8 1996. Madrid. Pág. 419-427.

- Sobre la norma de conflicto y su aplicación judicial: cinco cuestiones clásicas. Madrid. 1994.

Garcimartín Montero, R. Comentarios a la Ley de Enjuiciamiento civil. (Coordina de la Oliva Santos; Vegas Torres J; Díez Picazo Jiménez, I y Banacloche Palau, J;) L Pamplona 2001. Comentario al artículo 281.

- El objeto de la prueba en el proceso civil. 1997.

- La prueba de la costumbre y del derecho extranjero en el borrador de la LEC. Jornadas nacionales sobre el Anteproyecto de LEC. Murcia. 1997.

GaRde CASTILlo, J. Los problemas del recurso de casación en Derecho Internacional Privado. REDI Vol. IV. 1951, Pág. 409-467 y 861-951.

GoIdschmidt, J. Der prozess als rechtslage: eine kritik des prozessualen Denkens. Berlín 1925.

- Derecho Procesal Civil. Traducción de la segunda edición alemana y del código procesal civil alemán por Leonardo Prieto Castro con adiciones sobre la doctrina y la legislación española por Niceto Alcalá Zamora. Barcelona 1936. 
- Teoría general del proceso. Barcelona. 1936.

Gómez DE La SERna, P. Motivos de las variaciones principales que ha introducido en los procedimientos la ley de enjuiciamiento civil. Madrid. 1857.

GómEz GARRIDO, L.M. La aplicación judicial del derecho extranjero: implicaciones procesales. Revista doctrinal Aranzadi social. 2013.N. ${ }^{\circ} 5$.

Gómez Orbaneja, E. El ejercicio de los derechos. Madrid. 1975.

González Campos, J.D. Comentarios al artículo 12.3 Código Civil. Comentarios al Código Civil y Compilaciones Forales. Dirigidos por Albaladejo, M. Tomo I. Madrid. 1995.

- El paradigma de la norma de conflicto. Estudios jurídicos en homenaje al profesor Aurelio Menéndez. Civitas. Madrid. 1996. Pág. 5239-5270.

- Sobre la vinculación del juez a la ley en derecho internacional privado. Estudios en homenaje a Luís Diez Picazo. T. IV. Madrid. 2002. Pág. 6307-6322.

- Lecciones de derecho procesal civil internacional. Univ. Deusto. Bilbao. 1981.

González Pérez, J. El derecho a la tutela jurisdiccional. Madrid. 1984.

GuASCH Fernández, S. El hecho y el derecho en la casación civil. Barcelona. 1997.

Guasp Delgado, J. Comentarios a la Ley de Enjuiciamiento Civil. T. I y T. II (3. Vol.) Madrid. 1943-50

— Derecho Procesal Civil. 2.T. Madrid. 1968.

GutiérRez de Cabiedes e Hidalgo de Caviedes, E. Tratamiento procesal del derecho extranjero en el Título preliminar del Código Civil. Anuario de Derecho Internacional. Vol. II. 1975. Pamplona. Pág. 43-83.

GuZMÁn FluJA, V.C. El recurso de casación civil (control de hecho y de derecho). Valencia. 1996.

HedemanN, J.W. Las presunciones en el derecho. Traduce Luis Sánchez Seral. Madrid. 1931.

Herrero Rubio, A. Problemática de la aplicación del derecho extranjero. Anuario de Derecho Internacional. Vol. IV. Pamplona. 197778. Pág. 137-182 
Hinojosa y NAVERos, E. El elemento germánico en el derecho español. Madrid. 1915.

IRIARTE ÁngeL, J.L. Comentario al artículo 12 del Código Civil. Comentarios al Código Civil coordinados por Sierra Gil de la Cuesta, L. Barcelona. 2000.

Jiménez Blanco, P. Comentarios al artículo 281 LEC. Ley de Enjuiciamiento Civil Ley 1/2000). Comentarios. Coordina Gómez de Liaño, F. Oviedo. 2000. Pág. 348-350.

JimÉnez Conde, F. La apreciación de la prueba legal y su impugnación. Salamanca. 1978.

Lasso GaIte, J.F. Evolución histórica de la casación civil en España. RDPr. Iber.1971-1. Pág. 127-183.

López Fragoso Álvarez, T. La carga de la prueba según el art. 217 de la Ley de Enjuiciamiento Civil. Actualidad jurídica Aranzadi. N. ${ }^{\circ}$ 487. 2001. Pág. 1 y ss.

LÓPEz Simó, F. Disposiciones generales sobre la prueba. Comentario al art. 281 LEC. Comentarios a la nueva ley de Enjuiciamiento Civil. Coordinan De la Oliva Santos, A; Vegas Torres, J; Díez Picazo Jiménez, I; Banacloche Palao, J. Aranzadi. Navarra. 2001.

LORCA NAVARRETE, A.M. El denominado recurso extraordinario por infracción procesal que regula la nueva Ley de Enjuiciamiento Civil. Revista Vasca de Derecho Procesal y Arbitraje. Vol. 12. 20001-Pág. 21-28.

- El interés casacional en el recurso de casación que regula la Ley de Enjuiciamiento Civil. La Ley. 2000-2. Pág. 1694-1702.

- La fase intermedia de audiencia de las partes del juicio ordinario que regula la nueva Ley de Enjuiciamiento Civil. La Ley. 2000-1. Pág. 1735-1749.

- Tratado de Derecho Procesal Civil. Parte general. (con Lozano Higuero Pinto, M). San Sebastián. 2002.

Manresa Navarro, J.M. Comentarios al Código Civil Español. T. I. 1. a Edic. Madrid. 1890.

Martí MarTí, J. El interés casacional del Tribunal constitucional. La Ley 2002. N. ${ }^{\circ} 5656$.

Martín Ostos, J de los S. Comentario al artículo 281 LEC. Comentarios a la nueva Ley de Enjuiciamiento Civil. (Coordina Lorca Navarrete, A. M.) Valladolid. 2000. Pág. 1759. 
- La prueba. Aspectos generales. Instituciones del nuevo proceso civil. Coordina Alonso Cuevillas. T. II. Pág. 188 y ss. Barcelona. 2000.

- La prueba de oficio en el nuevo proceso civil. La Ley. N. ${ }^{0}$ 5. 1998. pág. 1786-1790. Y El proceso civil y la reforma. Coordina Manuel Morón Palomino. Madrid. 1998. Pág. 321-334.

— Las diligencias finales. Rev. Poder Judicial. N. ${ }^{\circ}$ 67. 2002. Pág. 381404.

— Las diligencias para mejor proveer. Madrid. 1981.

- Nueva regulación de las medidas para mejor proveer. Proserpina. Rev. UNED, Centro regional Mérida Extremadura. N. ${ }^{\circ}$ 3. 1985. Pág. 117-132.

MASEda RodRíguez, J. La aplicación judicial del derecho extranjero. El nuevo régimen de la LEC y la reciente jurisprudencia del Tribunal Constitucional. Actualidad civil. N. ${ }^{\circ}$ 12. 2002. pág. 413-418.

- En contra da desestimación da demanda en ausencia de proba do dereito extranxeiro. Revista Xurídica da Universidade de Santiago de Compostela. Vol. 15. N. ${ }^{\circ} 2$ 2000. Pág. 7-43.

Miaja de la Muela, A. Cuestiones referentes a la norma de conflicto. El reenvío. Estudios sobre el Título Preliminar del Código Civil. 2 T. Jaén 1977. Tomo II. Pág. 307-366.

Micheli, J.A. La carga de la prueba. Traduce Santiago Sentis Melendo. Buenos Aires. 1970. El título original de la obra es L'onere della prova. Padova.1942.

Miguel Alonso, C de. La problemática de la aplicación del derecho extranjero en el proceso. Libro homenaje al profesor Barcia Trelles. Santiago de Compostela 1958. Pág. 503 y ss.

Miralles Sangro, P. P. Aplicación del derecho extranjero en el proceso y tutela judicial. Madrid. 2007.

- Constitucionalización de las garantías procesales y Derecho Procesal Civil Internacional en España. UNED. Madrid. 1990

Montero Aroca (con Flors Maties, J). El recurso de casación civil (casación e infracción procesal). Valencia. 2012.

- La prueba en el proceso civil. Madrid. 2011.

- La valoración de la prueba y su impugnación tras la reforma del recurso de casación civil. La Ley. 1993. 
- Presentación de documentos materiales con la demanda y la contestación. Rev. Poder Judicial. N. o 17. 1990. Pág. 37-68.

Morón Palomino, M. Ensayo sobre el origen y evolución del recurso de casación en Francia. Anales Facultad de Derecho de la Universidad de la Laguna. N. ${ }^{\circ} 14$. 1997. Pág. 75-86.

- Problemática del derecho extranjero en casación. Anales de la Facultad de Derecho de la Universidad de La Laguna. N. ${ }^{\circ}$ 18. 2001. Pág. 383-399.

Muerza Esparza, J.J. El motivo 1. ${ }^{\circ}$ del artículo 1692 de la LEC de 1881 y su evolución. Pamplona 1986.

Muñoz Sabaté, L. Fundamentos de prueba judicial civil. LEC 1/2000. Barcelona. 2001.

- Técnica probatoria. (Estudios sobre las dificultades de la prueba en el proceso). Barcelona. 1993.

NAVARRo Hernán, M. El documento auténtico y la casación civil y penal. Madrid. 1977.

Nieva Fenoll, J. La valoración de la prueba. Madrid. 2010.

- Los sistemas de valoración de la prueba y de la carga de la prueba: nociones que precisan revisión. Justicia. 2011. 3 y 4. Pág. 91-120.

Oliva SAntos, A. de la. Comentarios a la Ley de Enjuiciamiento civil (con Banacloche Palao, J, Vegas Torres, J; Díez Picazo Jiménez, I). Pamplona. 2001.

- La presentación de documentos en juicio. Rev. Der. Proc. Iberoamericana. 1970-4.

- Sobre el derecho a la tutela jurisdiccional. La persona ante la Administración de Justicia: derechos básicos. Madrid. 1980.

ORDoÑo ARTES. Aspectos procesales de la prueba en el proceso civil. Granada. 1988

OrLandis RoviRa, J. Historia del reino visigodo español. Madrid. 1988.

Ormazabal SÁNChez, G. Discriminación y carga de la prueba en el proceso civil. Madrid. 2011.

Ortiz Arce de la Fuente, A. Algunas consideraciones en torno al Derecho Internacional Privado español. Pasado y presente. Soberanía del Estado y Derecho Internacional. Homenaje al profesor Juan Antonio Carrillo Salcedo. T. II. Pág. 966 y ss. Sevilla. 2005. 
- Comentario al artículo 12 del Código Civil. Comentarios al Código Civil coordinados por Rams Albesa, J. Y Moreno R.M. Barcelona. 2000. Pág. 346-65.

Paz Romero, M. P. El solemne orden de los juicios: la lentitud como problema en la historia del proceso de Castilla. Anuario de la Facultad de Derecho de la facultad de Derecho de la UAM. N. 5. 2001. Pág. 23-54.

Pecourt García, E. Naturaleza y condición del derecho extranjero reclamado por la norma de conflicto. RGD. 1962.

- Una institución singular en la Historia del Derecho Internacional Privado Español: el fuero de extranjería. Estudios de Derecho Internacional Público y Privado. Homenaje al profesor Luís Sela. Universidad de Oviedo. 1970.

PÉREZ, M.M; Benavides, V. La teoría estatutaria como solución al conflicto entre el Derecho Internacional de los distintos Reinos. A propósito de una sentencia de una Chancillería de Granada en el S. XVIII. Initium. 2001. Pág. 445-468.

Pérez Bebiá, J.A. La aplicación del derecho público extranjero. Universidad de Sevilla. 1989.

PÉREZ DAUdí, V. La carga de la prueba como medio procesal para la protección del derecho de igualdad en el orden civil. Justicia. 2015-1. Pág. 111-141.

Pérez Prendes Muñoz-Arraco, J.M. Historia del Derecho Español. Parte general. Madrid. 1963.

- Leyes por la brevedad y orden de los pleitos de 1499. Reforma procesal de la Reina Isabel. Arbor. CLVIII. 701. Mayo 2004. pág. 87 a 106.

PÉrez Voiturez, A. El procedimiento de información de la ley extranjera en el Derecho Español. Madrid. 1988.

- La información de la ley extranjera en el derecho internacional privado. Correspondencia del desarrollo de la técnica de cooperación internacional con la naturaleza y función del Derecho Internacional Privado. Madrid. 1988.

- Naturaleza y valoración de la ley extranjera en el derecho español. Publicaciones de la Universidad de la Laguna 1975.

Pico Junoy, J. El conocimiento científico en el proceso civil. Rev. Jur. Cat. Vol. 110. 2011-1. Pág. 293. 
- El derecho a la prueba en el proceso civil. Barcelona. 1996.

- El juez y la prueba: estudio de la errónea recepción del brocardo iudex iudicare debet secundum allegata et probata non secundum conscientiam y su repercusión actual. Barcelona. 2002.

- El principio de adquisición procesal en materia probatoria. La Ley. 2006. Pág. 1304-1314.

- La iniciativa probatoria del juez civil. Advocatus. N. ${ }^{\circ}$ 18. 2008. Pág. 73-90.

- La iniciativa probatoria del juez civil y sus límites. Poder judicial. 3. ${ }^{a}$ época. $3^{\circ}$. Trimestre. N. ${ }^{\circ}$ 51. 1998. Pág. 269-301.

- La iniciativa probatoria del juez civil: a propósito de un caso. Los poderes del juez en materia probatoria. Seminario de estudio de la Escuela Judicial. Barcelona. 2003. Pág. 137-174.

- La prueba pericial en el proceso civil español. Barcelona. 2001.

- Práctica probatoria del derecho extranjero. La Ley. Madrid. 2011.

Plaza Navarro, M de la. La casación civil. Madrid. 1944.

RAmos MÉndeZ, F. Eficacia ejecutiva en España de las letras de cambio extranjeras. Justicia. 1983.-2. Pág. 340-348.

- Jurisprudencia procesal internacional. Justicia. 1987-1 Pág. 145188 y Justicia 1991-2. Pág. 369-418

- La prueba del derecho extranjero. Rev. Jur. De Cataluña. 1980. Pág. 659-675.

- Inaplicación de la norma de conflicto que remite al derecho extranjero. Justicia.2002-3 y 4. Pág. 169-179. Y en homenaje a Don Eduardo Font Serra. T. II. Vol. I. 2004. Pág. 495-504.

- Procesal Internacional. Justicia. 1985-3. Pág. 691-722. Y Justicia 1986-1. Pág. 169-222.

RECONDO, R. El sistema del fuero de extranjería. (Contribución de la competencia internacional de los tribunales españoles). Estudios de Deusto. XXVI, XXVII, XXVIII. 1978-1980.

Ríos LóPEZ, Y. ¿Puede el juez, al amparo del artículo 429-1 LEC proponer una fuente de prueba distinta de la propuesta por las partes? ¿Es necesario que la prueba propuesta conste nominatium en los autos, o basta que se desprenda de los mismos? Problemas actuales de la prueba civil. Barcelona. 2005. 
Rossemberg, L. La carga de la prueba. Traduce Ernesto Krotoschin. Buenos Aires. 1956.

Ruiloba Santana, E. Sobre el concepto y delimitación del orden público en el Derecho Internacional Privado. RGLJ. 1974. pág. 640 y ss.

Sentis Melendo, S. La prueba. El juez y el derecho. Pág. 205 y ss. Los grandes temas del derecho probatorio. Buenos Aires. 1978.

- Iniciativa probatoria del juez en el proceso civil. Rev. Der. Proc. Iber. 1971. 2 y 3. Pág. 591

Seoane Spiegelberg, J.L. La prueba en la Ley de Enjuiciamiento Civil. Pamplona. 2002.

SERna Vallejo, M. El régimen legal de las alegaciones jurídicas en la Corona de Castilla y en los Reinos de Navarra y de la Corona de Aragón en la Baja Edad Media y en la moderna. Ius Fugit. Revista Interdisciplinar de estudios histórico-jurídicos. N. ${ }^{\circ}$ 17. 2011-14. Pág. 11 a 54.

Serra Domínguez, M. Comentarios al Código Civil y Compilaciones forales. La prueba de las obligaciones. Vol.XVI-II. Madrid.1981.

- Contribución al estudio de la prueba. Estudios de Derecho Procesal. Barcelona. 1969. Pág. 367 y ss.

- La prueba. Aspectos generales. Instituciones del nuevo proceso civil. Comentarios sistemáticos a la ley 1/2000. Coordina Alonso Cuevillas Sayrol. Barcelona. 2000. Pág. 367.

- El juicio jurisdiccional. Estudios de Derecho Procesal. Barcelona. 1969.

Silva Melero, V. La prueba civil. 2.Tomos.Madrid. 1963.

STEIN, F. El conocimiento privado del juez. Traduce Andrés de la Oliva Santos. Pamplona. 1973

TARufFo, M. La prueba de los hechos. Traduce Jordi Ferrer Beltrán. Madrid. 2005. El título original es: La prova dei fatti giuridici. Milano. 1992.

TOMÁs ORTIZ DE LA TORRE, J.A. El régimen de la extranjería en la España del S. XVIII y la participación del extranjero en la industria nacional. Madrid. 1972.

Tomás y Valiente, F. Manual de Historia del Derecho Español. Madrid. 1981. 
UREÑa y SMENJAUd, R. La legislación gótico-hispánica (Leyes antiquiores liber iudiciorum). Estudio crítico. Madrid. 1905.

VALLejo Fernández de la Reguera, J. La regulación del proceso en el Fuero Real. Desarrollo, precedentes y problemas. AHDE. N. ${ }^{\circ} 55$. 1985 pág. 495-704.

VAllespín PÉRez, D. La prueba del derecho extranjero en la Ley 1/2000 de Enjuiciamiento Civil. Justicia. 2000-1. Pág. 35-42.

VANNI. La prova del diritto straniero. Milano. 1971.

VÁzouez Sotelo, J.L. Iniciativas probatorias del juez en el proceso civil. Justicia 2009-1 y 2. Pág. 21-74.

- Los principios del proceso civil. Ensayo doctrinal. Responsa iurisperitorum digesta. Coordina Fabián Caparrós. Vol. 1. Salamanca. 2000. Pág. 111-156. y también en Justicia. 1993-4. Pág. 599-645.

VERDI, G. L'onere della prova nel processo civile. Milano. 1974.

Vicente y CaRavantes, J. Tratado histórico crítico filosófico de los procedimientos judiciales en materia civil según la nueva ley de enjuiciamiento con sus correspondientes formularios. 3T. Madrid. 1856-58.

Villagómez Cebrián, M. La prueba. La nueva ley de enjuiciamiento civil. (Coordina Cortés Domínguez, V y Moreno Catena, V). Tomo III. Madrid. 2000. Pág. 304 y ss.

Villaverde Ferreiro. Comentario al artículo 281 LEC (coordina Lledó Yagüe). Comentarios a la nueva Ley de Enjuiciamiento Civil. Madrid. 2000.

VIVES, J. Concilios visigóticos e hispanoromanos (con la colaboración de Tomás Marín Martínez y Gonzalo Martínez Díez). Madrid. 1953. 